\title{
All about neosporosis in Brazil
}

\author{
Tudo sobre neosporose no Brasil \\ Camila Koutsodontis Cerqueira-Cézar ${ }^{1}$; Rafael Calero-Bernal ${ }^{1}$; Jitender Prakash Dubey ${ }^{1}$; Solange Maria Gennari ${ }^{2 *}$ \\ ${ }^{1}$ Animal Parasitic Diseases Laboratory, Beltsville Agricultural Research Center, United States Department of Agriculture, Agricultural \\ Research Service, Beltsville, MD, United States of America \\ ${ }^{2}$ Departamento de Medicina Veterinária Preventiva e Saúde Animal, Faculdade de Medicina Veterinária e Zootecnia, Universidade de \\ Sáo Paulo - USP, São Paulo, SP, Brasil
}

Received January 22, 2017

Accepted June 28, 2017

\begin{abstract}
Neospora caninum is protozoan parasite with domestic and wild dogs, coyotes and grey wolves as the definitive hosts and many warm-blooded animals as intermediate hosts. It was cultivated and named in 1988 . Neosporosis is a major disease of cattle and has no public health significance. Since 1990's N. caninum has emerged as a major cause of abortion in cattle worldwide, including in Brazil. $N$. caninum also causes clinical infections in several other animal species. Considerable progress has been made in understanding the biology of $N$. caninum and there are more than 200 papers on this subject from Brazil. However, most of the reports on neosporosis from Brazil are serological surveys. Overall, little is known of clinical neosporosis in Brazil, particularly cattle. The few reports pertain to sporadic cases of abortion with no information on epidemics or storms of abortion. The objective of the present review is to summarize all reports from Brazil and suggest topic for further research, including prevalence of $N$. caninum oocysts in soil or in canine feces, and determining if there are additional definitive hosts, other than the domestic dog. There is need for a national survey in cattle using defined parameters. Future researches should focus on molecular characterization of $N$. caninum strains, possibility of vaccine production and relationship between wildlife and livestock epidemiology.
\end{abstract}

Keywords: Neospora caninum, neosporosis, domestic animals, wild animals, Brazil.

\section{Resumo}

Neospora caninum é um protozoário parasita que possui os canídeos domésticos e selvagens, coiotes e lobos cinzentos como hospedeiros definitivos e vários animais de sangue quente como hospedeiros intermediários. Foi cultivado e nomeado em 1988. A neosporose é uma das principais doenças em bovinos e não tem significância em saúde pública. Desde 1990, $N$. caninum tem emergido como uma das principais causas de aborto em bovinos em todo o mundo, inclusive no Brasil. $N$. caninum também causa infecçóes clínicas em várias outras espécies animais. Consideráveis avanços foram feitos na compreensão da biologia desse parasita e há mais de 200 trabalhos sobre o assunto no Brasil. No entanto, a maioria dos relatos de neosporose do Brasil são relacionados a sorologia. Em geral, pouco se sabe sobre a neosporose clínica no Brasil, particularmente em bovinos. Os poucos relatos referem-se a casos esporádicos de aborto sem informaçóes sobre epidemias ou surtos de aborto. O objetivo da presente revisão é resumir todos os relatos sobre $N$. caninum no Brasil e sugerir tópicos para pesquisas futuras, incluindo a prevalência de oocistos de $N$. caninum no solo ou em fezes caninas e determinar se há hospedeiros definitivos adicionais, exceto o cão doméstico no país. Uma pesquisa nacional em bovinos usando parâmetros definidos seria de grande importância. Pesquisas futuras deveriam ser focadas na caracterização de cepas de $N$. caninum, possibilidade de produção de vacinas e a relação epidemiológica entre a vida selvagem e o gado.

Palavras-chave: Neospora caninum, neosporose, animais domésticos, animais selvagens, Brasil.

\footnotetext{
*Corresponding author: Solange Maria Gennari. Departamento de Medicina

Veterinária Preventiva e Saúde Animal, Faculdade de Medicina Veterinária

e Zootecnia, Universidade de São Paulo - USP, Av. Prof. Orlando Marques

de Paiva, 87, Cidade Universitária, CEP 05508-270, São Paulo, SP, Brasil.

e-mail: sgennari@usp.br
} 


\section{Introduction}

Neosporosis is relatively a newly recognized disease. In 1988, the etiologic agent of neosporosis was cultivated and named, Neospora caninum. It is ancestrally and morphologically related to Toxoplasma gondii. Since 1990's $N$. caninum has emerged as a major cause of abortion in cattle worldwide, including in Brazil. $N$. caninum also causes clinical infections in several other animal species. Considerable progress has been made in understanding the biology of $N$. caninum. A recent book on neosporosis (DUBEY et al., 2017) listed more than 2100 citations and most reports (>200) from Brazil. Many of the reports from Brazil are scattered in local journals. The objective of the present review is to summarize reports from Brazil and suggest topic for further research. To minimize citations, only references from Brazil are listed in bibliography.

\section{Basic Biology}

As stated earlier, N. caninum and T. gondii are morphologically similar but biologically different coccidians. Both parasites have a wide host range but unlike T. gondii, N. caninum is not considered zoonotic. Canids (domestic and wild canids dogs, coyote, and wolf) are the definitive hosts of $N$. caninum whereas felids (domestic and wild Felidae) are definitive hosts for $T$. gondii. Neosporosis is a major disease of cattle whereas cattle are considered resistant to T. gondii. Transplacental transmission is a major route of propagation of $N$. caninum in cattle while, although medically important, is not the major route of transmission for $T$. gondii. There is only one species of Toxoplasma, T. gondii, but the genus Neospora has two species, $N$. caninum and $N$. hughesi; only horses are reported as an intermediate host for $N$. hughesi.

\section{History of Neosporosis in Brazil}

The in vitro cultivation of $N$. caninum in 1988 in USA made it possible to develop diagnostic tests for neosporosis (DUBEY et al., 2017). However, unlike T. gondii, it is difficult to culture N. caninum (see later discussion) and only one isolate (NC-1) was available initially at the USDA laboratory in Beltsville, Maryland, USA. Thus, commercial tests were not developed for the diagnosis of neosporosis for several years. Therefore, no research was performed on this subject in Brazil until mid 1990's.

In BA, Gondim et al. (1999b, 2001) first recognized clinical neosporosis in an aborted bovine fetus and first isolated viable $N$. caninum (NC-Bahia) from the brain of a naturally-infected adult dog presenting incoordination and hind-limb paresis. Corbellini et al. (2002) first recognized neosporosis as an important cause of bovine abortion. They documented lesions consistent with protozoal infection in $22(47.8 \%)$ of 46 fetuses submitted from 12 farms in RS. From those, 18 specimens of fetuses with encephalitis reacted to $N$. caninum antisera.

\section{Brazilan Contributions to the General Biology of $N$. caninum}

\section{Viable N. caninum isolates and genetic diversity}

Unlike $T$. gondii, little is known of genetic diversity of $N$. caninum mainly because there are only few viable isolates available worldwide. One reason for this is the difficulty to isolate viable $N$. caninum from animal tissues, especially from latently infected animals. Table 1 summarizes all viable isolates of $N$. caninum from animals in Brazil. The greatest success of isolating Neospora from asymptomatic animals has been achieved by feeding brain tissue from naturally-infected animals to dogs and then examining dog feces for oocyst excretion. By doing so, $N$. caninum was isolated from buffaloes, sheep and cattle.

In addition, to provide these Neospora isolates for biological and genetic studies to researchers in other countries (DUBEY et al., 2017), García-Melo in association with researchers from Spain did the first microsatellite typing data for Nc-Goiás isolated from clinically healthy cattle. Although the isolate had most of the alleles already identified, unique alleles were described for this strain at the MS5 and MS10 loci, using 12 microsatellite markers (GARCÍA-MELO et al., 2009). The recent isolate from brain tissue from a naturally-infected cattle (OLIVEIRA et al., 2017) was also found to have unique microsatellite alleles as MS5, MS6a, MS8 and MS10. A dog fed brain tissue from a naturally-infected cattle excreted $N$. caninum oocysts for 14 days starting seven days post infection (dpi), with an average number of 102 oocysts/g of feces. DNA isolated from cell culture derived tachyzoites was characterized using microsatellites. No new alleles were found and comparison showed closest relation to multilocus genotyping with strains from Spain and Argentina. Comparison with Brazilian strains (NC-Bahia; NC-Goiás) revealed variation in three and four of the nine markers used.

Additionally, the Brazilian NC-Bahia strain isolated from the dog was included among the $N$. caninum strains characterized by researchers outside Brazil (AL-QASSAB et al., 2009, 2010; REGIDOR-CERRILLO et al., 2013).

\section{Transmission}

Tachyzoites (in groups), bradyzoites (in tissue cysts) and sporozoites (in oocysts) are the three infectious stages of $N$. caninum. Tachyzoites and bradyzoites occur in tissues of intermediate hosts whereas oocysts are excreted in feces of certain canids. Unlike $T$. gondii, relatively few oocysts are excreted by canids after ingesting infected tissues. However, oocysts were excreted with a high frequency by two-three-month old dogs fed brains from six naturally infected water buffaloes (RODRIGUES et al., 2004). An other study showed that oocyst excretion is more efficient by feeding brains than other tissues to dogs (CAVALCANTE et al., 2011). The authors fed 17 two-three month old dogs with different tissues from four cattle naturally infected with $N$. caninum. Each group of dogs received: masseter $(n=5)$, heart $(n=5)$, brain 
Table 1. Isolation of $N$. caninum from naturally infected animals from Brazil.

\begin{tabular}{|c|c|c|c|c|c|c|c|}
\hline \multirow{2}{*}{ Host } & \multirow{2}{*}{ Source } & \multicolumn{2}{|c|}{ Bioassay } & \multirow{2}{*}{$\begin{array}{c}\text { Isolate } \\
\text { designation }\end{array}$} & \multirow{2}{*}{$\begin{array}{l}\text { Genetic } \\
\text { data }\end{array}$} & \multirow{2}{*}{ Remarks } & \multirow{2}{*}{ Reference } \\
\hline & & Animals & Cell culture & & & & \\
\hline \multirow{4}{*}{ Cattle } & $\begin{array}{l}\text { Clinical, blind, } \\
\text { neurological calf, } \\
\text { 3-months old }\end{array}$ & SW mice, & Vero & $\mathrm{BCN} / \mathrm{PR} 3$ & No & $\begin{array}{l}\text { Tissue cysts were found in the } \\
\text { brains of SW mice that were } \\
\text { immunocompetent }\end{array}$ & $\begin{array}{l}\text { Locatelli- } \\
\text { Dittrich et al. } \\
\quad(2003)\end{array}$ \\
\hline & $\begin{array}{l}\text { Aborted fetus, } \\
7 \text { months of } \\
\text { gestation }\end{array}$ & Mice, gerbils & Vero & $\mathrm{BCN} / \mathrm{PR} 1$ & Yes & $\begin{array}{l}\text { Initial isolation in immunosuppressed } \\
\text { mice. Tachyzoites infective to } \\
\text { immunocompetent mice and gerbils }\end{array}$ & $\begin{array}{l}\text { Locatelli- } \\
\text { Dittrich et al. } \\
\quad(2004)\end{array}$ \\
\hline & $\begin{array}{l}\text { Asymptomatic, } \\
4 \text { months old }\end{array}$ & KO mice & MARC-145 & Nc-Goiás 1b & Yes & Not pathogenic to $\mathrm{BALB} / \mathrm{c}$ mice & $\begin{array}{c}\text { García-Melo et al. } \\
\text { (2009) }\end{array}$ \\
\hline & $\begin{array}{l}\text { Adult slaughtered } \\
\text { in abattoir }\end{array}$ & $\begin{array}{l}\text { Dog, SW } \\
\text { mice, gerbils }\end{array}$ & Vero & NC-SP1 & Yes & Isolated from dog bioassay & $\begin{array}{c}\text { Oliveira et al. } \\
\text { (2017) }\end{array}$ \\
\hline Dog & $\begin{array}{l}\text { Collie, } 7 \text { years } \\
\text { old, clinical }\end{array}$ & Gerbil & Vero (COS-1) & NC-Bahia & Yes & Isolate pathogenic to gerbils & $\begin{array}{l}\text { Gondim et al. } \\
(2001,2004)\end{array}$ \\
\hline Sheep & $\begin{array}{l}\text { Two } 4 \text { months } \\
\text { old, clinically } \\
\text { normal }\end{array}$ & $\begin{array}{l}\text { Gerbil, SW } \\
\text { and vesper } \\
\text { mice, dogs }\end{array}$ & Vero & Not stated & No & $\begin{array}{l}\text { Mice remained healthy. Necropsied } \\
60 \text { dpi. Tissue cysts in brains of both } \\
\text { gerbils. }\end{array}$ & Pena et al. (2007) \\
\hline $\begin{array}{l}\text { Water } \\
\text { buffalo }\end{array}$ & $\begin{array}{l}6 \text { seropositive } \\
\text { from abattoir }\end{array}$ & $\begin{array}{l}\text { Dogs, gerbil, } \\
\text { KO mice }\end{array}$ & CV1 & $\begin{array}{l}\text { NCBrBuf-1 } \\
\text { NCBrBuf-2 } \\
\text { NCBrBuf-3 } \\
\text { NCBrBuf-4 } \\
\text { NCBrBuf-5 }\end{array}$ & No & $\begin{array}{l}\text { Both gerbils and } \mathrm{KO} \text { remained } \\
\text { asymptomatic }\end{array}$ & $\begin{array}{l}\text { Rodrigues et al. } \\
\qquad(2004)\end{array}$ \\
\hline
\end{tabular}

$\mathrm{KO}=$ Gamma interferon gene knockout; $\mathrm{SW}=$ Swiss Webster.

$(\mathrm{n}=4)$, liver $(\mathrm{n}=3)$, and a group remaining as control $(\mathrm{n}=3)$, no infected. None of the control dogs excreted oocysts and three dogs that received brain, two that received masseter, two that received heart and one that received liver excreted $N$. caninum-like oocysts, from day seven to day 17 after ingestion of tissues. All dogs that received brain and liver excreted only $N$. caninum oocysts. The results were confirmed by polymerase chain reaction (PCR) using Nc5 and ITS-1 amplification and indicated that a variety of visceral, neural, and muscular tissues are infected naturally with $N$. caninum.

How dogs become infected with $N$. caninum in nature is not fully understood. Fecal transmission of $N$. caninum in dogs appears to be less important than carnivorism. Until the study by Bandini et al. (2011) it was unknown if the dogs could be infected via ingestion of oocysts. They fed four dogs with 1,000, 5,000 or 10,000 N. caninum oocysts; none of the four dogs excreted $N$. caninum-like oocysts in their feces during the observation period of 30 days. However, the two dogs fed with 10,000 oocysts seroconverted and the two dogs fed with 1,000 or 5,000 oocysts did not. Neither parasite DNA nor parasite stages were demonstrable in tissues of the seropositive dogs euthanized six months after feeding oocysts. These findings suggest that fecal transmission may not be an important mode of transmission of the parasite for the definitive host but results need confirmation.

Tachyzoites are important in transplacental transmission of $N$. caninum infection. Cavalcante et al. (2012) confirmed transplacental transmission of $N$. caninum in dogs. Six bitches in two groups were inoculated with a very high dose ( $10^{8}$ tachyzoites). In group I, three bitches were inoculated during the third week of gestation, and in group II, three bitches were inoculated at the sixth week of gestation. The bitches were allowed to whelp naturally. Dams and their pups were tested by immunohistochemistry (IHC), serology, and PCR. In group I, six of the ten pups died within 48 hour of birth. In group II, seven of the 13 pups died between five and ten days of birth. $N$. caninum DNA was detected by nested PCR in two pups (hearts of both and liver of one) from group I, and one pup in central nervous system (CNS) and lymph node from group II. The dams and the pups that survived were clinically normal. N. caninum was not demonstrable in tissues of any of pups and their dams.

Studies in Brazil showed that N. caninum can be transmitted transplacentally in water buffaloes (CHRYSSAFIDIS et al., 2014, 2015). The authors conducted an important experiment in six buffaloes and seven cows inoculated intravenously with $N$. caninum tachyzoites at 70 day of gestation. Three buffaloes and five cows were inoculated with a Brazilian $N$. caninum strain (NC-Bahia); only one cow aborted but all fetuses became infected. The other two cows and three buffaloes were inoculated with the NC-1 strain; all fetuses died by $35 \mathrm{dpi}$ as determined by ultrasound and N. caninum DNA was detected in fetal tissues.

Chryssafidis et al. (2011) also showed, for the first time, that $N$. caninum can be transmitted transplacentally in naturally infected buffaloes; they found $N$. caninum DNA in one brain of the nine fetuses from buffaloes slaughtered in an abattoir, aiming Nc5 and ITS-1 DNA regions. Although, viable or intact parasite has not been demonstrated in naturally infected fetuses from buffaloes, this is the first indication of transplacental transmission in this host. 
In addition to bradyzoites and oocysts, tachyzoites can also be infectious orally. Four to five day old gerbils were successfully infected by oral inoculation of tachyzoites (FERREIRA et al., 2016). All 17 gerbils died of neosporosis between eight and $17 \mathrm{dpi}$ (one died on each of days $8,9,15,16$, and 17 , four died on day 12 , and five died on day 15 (personal communication to JPD on October $24,2016)$ with 4 x $10^{5} \mathrm{NC}-1$ tachyzoites. $N$. caninum DNA was found in heart, lung, spleen, kidney, liver and CNS of gerbils.

\section{Environmental resistance of oocysts}

Oocyst is the environmentally resistant stage. Researchers in Brazil found that $N$. caninum oocysts were rendered noninfectious by heating to $100{ }^{\circ} \mathrm{C}$ for one minute, and $10 \%$ sodium hypochlorite for one hour but not at $60{ }^{\circ} \mathrm{C}$ for one minute, and by other commonly used disinfectants (ALVES et al., 2011). Aqueous $2 \%$ sulfuric acid has been commonly used to store $N$. caninum oocysts at $4{ }^{\circ} \mathrm{C}$; how long oocysts remain viable under these conditions is not known. $N$. caninum oocysts remained viable for 108 days but not for 46 months when stored in 2\% sulfuric acid at $4{ }^{\circ} \mathrm{C}$ (UZÊEA et al., 2007a).

\section{Diagnostic tests}

Recently, Fehlberg et al. (2017) reported on successful development of a high resolution melting PCR method to distinguish Neospora, Sarcocystis and Toxoplasma using a single pair of primers targeting $18 \mathrm{~S}$ rDNA.

\section{Epidemiology}

More serological studies for $N$. caninum infection in animals have been conducted in Brazil than rest of the world.

The results, however, are not comparable because of different serological assays used different cut-offs employed, different antigens used. For example, in the indirect fluorescent antibody test (IFAT) and the Neospora agglutination test (NAT) whole tachyzoites are used detecting antibodies to surface proteins whereas in the enzyme-linked immunoabsorbent assay (ELISA) different antigens are used, some of them using crude tachyzoite extract while others used soluble antigens (Table $2 \mathrm{a}$ ). The standardization of serological tests was based on studies in other countries and a full discussion of these is beyond the scope of this review-this subject was recently reviewed (DUBEY et al., 2017). One of the problems with serological testing is the availability of standardized sera from experimentally infected animals. Immunoblotting (IB) was employed in some studies where no such sera were available (Table 2b).

Little has been done in Brazil to characterize Neospora recombinant antigens for the serological diagnosis or vaccine development, except the report of Bezerra et al. (2017) who characterized one surface protein, by cloning the sequence and named it as NcSRS67, which has no orthologue with Toxoplasma gondii, only with Hammondia hammondi.

In Tables 3-12 serological reports in different hosts are summarized. We listed all reports that we found.
Salient features are commented for some of these surveys.

Dogs: Numerous surveys from different regions of Brazil are summarized in Table 3. As stated earlier results of these types of surveys are not strictly comparable. However, 45 of 49 surveys used IFAT as a diagnostic technique, and most of them employed the cut-off value of 1:50, facilitating comparisons of occurrence values. In three surveys, IFAT and ELISA were compared for serological diagnosis of $N$. caninum in dog sera and IFAT was superior to indirect ELISA used (SILVA et al., 2007; HIGA et al., 2000; RAIMUNDO et al., 2015).

In some studies, risk factors were evaluated (Table 3). The age of dogs was a statistically significant factor in nine reports; older dogs were more likely to be seropositive (OLIVEIRA et al., 2004; FERNANDES et al., 2004; AZEVEDO et al., 2005; ANDREOTTI et al., 2006; CUNHA et al., 2008; MINERVINO et al., 2012; NOGUEIRA et al., 2013; BALTHAZAR et al., 2013; RAIMUNDO et al., 2015). Gender and breed were not associated with presence of antibodies. In two surveys mixed breed dogs constituted a risk factor for the infection (BRUHN et al., 2012; RAIMUNDO et al., 2015). The diet in some studies was related with access to street and prevalence was higher in dogs that had outdoor access than in pets with little or no outdoor scavenging (GENNARI et al., 2002; CAÑÓN-FRANCO et al., 2003; BENETTI et al., 2008; SICUPIRA et al., 2012). However, in some studies such an association was not found (MINEO et al., 2004; JESUS et al., 2006; PLUGGE et al., 2011). Vertical transmission was also studied (TAQUES et al., 2016), with 41 stillborn puppies from 23 bitches. By PCR and IFAT, five (21.7\%) bitches were positive and 22 (53.6\%) stillborn were positive by PCR, utilizing ITS-1 DNA region/locus, being 17 from positive bitches and five from negative ones. Although the prevalence of positive stillborn was higher from positive bitches, no conclusions were made.

Epidemiologically, contact between cattle and dogs has been identified as a possible risk factor that deserves attention (Table 3). Dogs from peri-urban or rural areas had more chance to be infected by $N$. caninum (IFAT 1:50) than urban dogs in the surveys from MG (FERNANDES et al., 2004), PR (PLUGGE et al., 2008), RS (CUNHA et al., 2008), and BA (SICUPIRA et al., 2012), and this risk factor is normally associated with proximity to cattle; access and ingestion of fetal membranes, carcasses, and prey.

Leishmania infantum chagasi is an important parasite of dogs in Brazil; and immunosuppression caused by Leishmania spp. may enhance the susceptibility of dogs to $N$. caninum infection (CRINGOLI et al., 2002). Serological surveys correlating N. caninum and Leishmania spp., had been conducted (GENNARI et al., 2006; ANDREOTTI et al., 2006; GUIMARÁES et al., 2009; GRECA et al., 2010; VALADAS et al., 2010a; LOPES et al., 2011; PAULAN et al., 2013; SEABRA et al., 2015; CONSTANTINO et al., 2016). In dogs from endemic cities of visceral leishmaniosis such as Araçatuba, SP (GENNARI et al., 2006), Campo Grande, MS (ANDREOTTI et al., 2006), and Teresina, PI (LOPES et al., 2011), positive association was found (Table 3).

Cattle: Seroprevalence of $N$. caninum varied with the type of cattle (beef, dairy), different regions, within region and with the type of serological tests used (Table 4). 
Table 2a. ELISA techniques used to confirm presence of $N$. caninum antibodies.

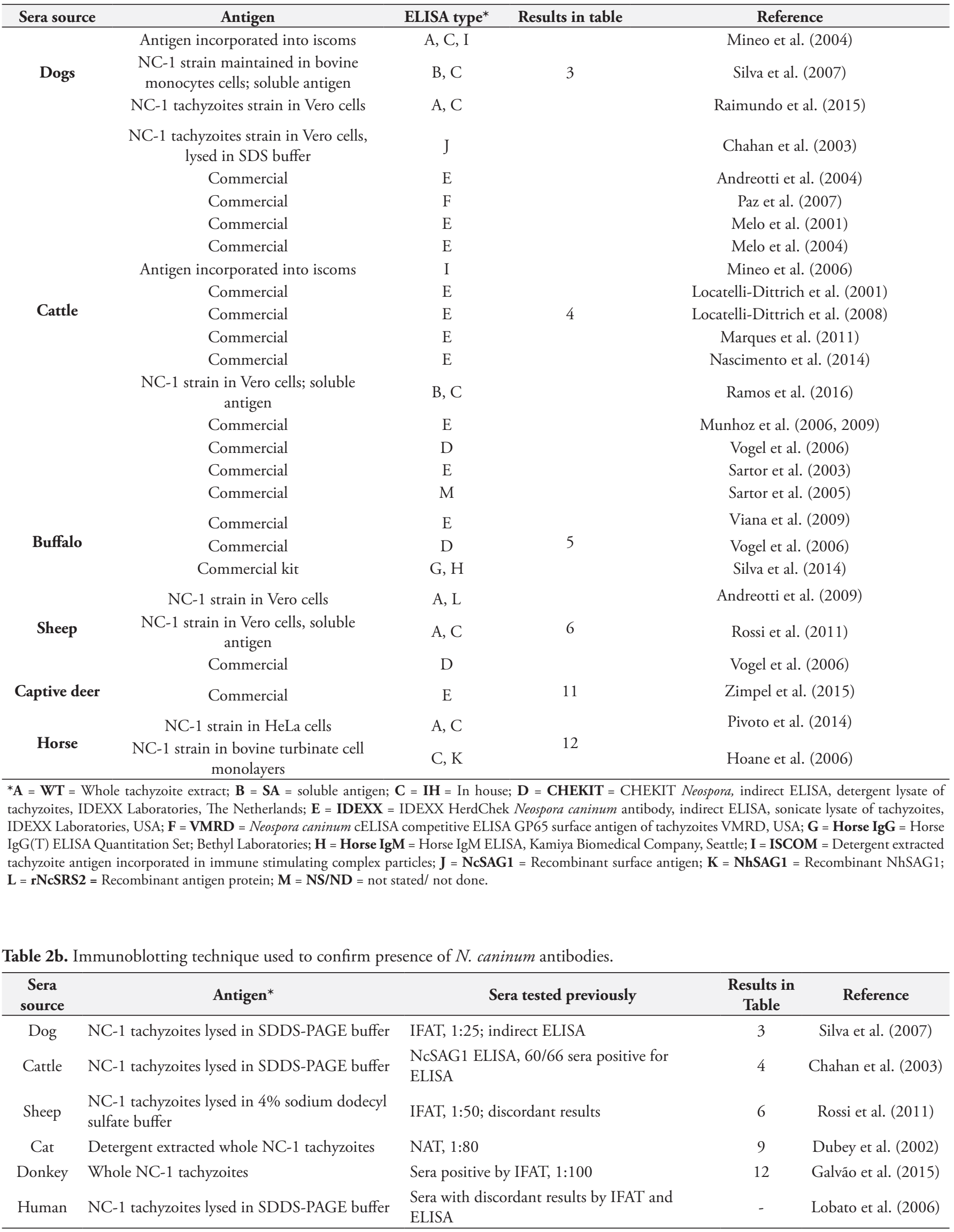




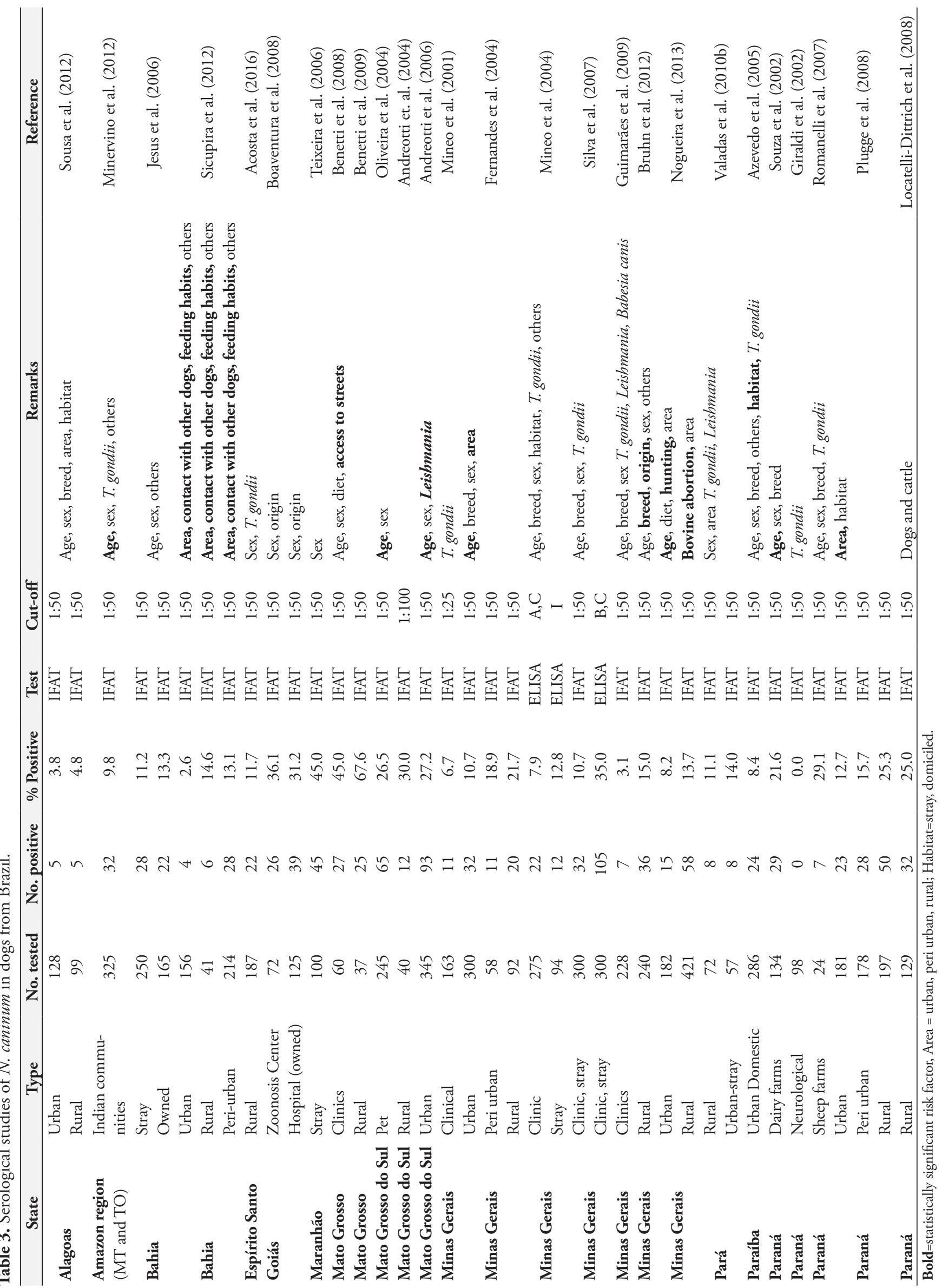




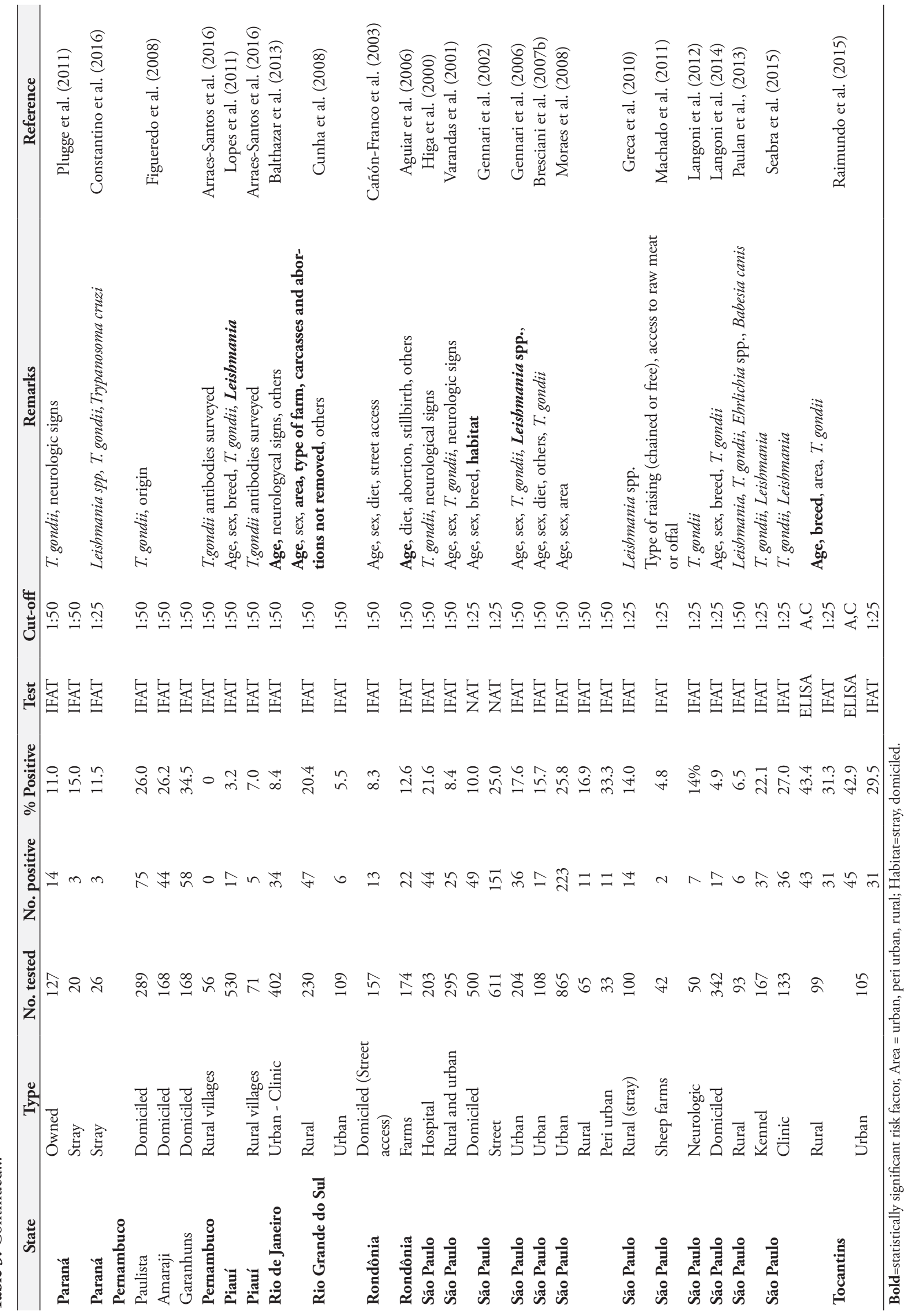




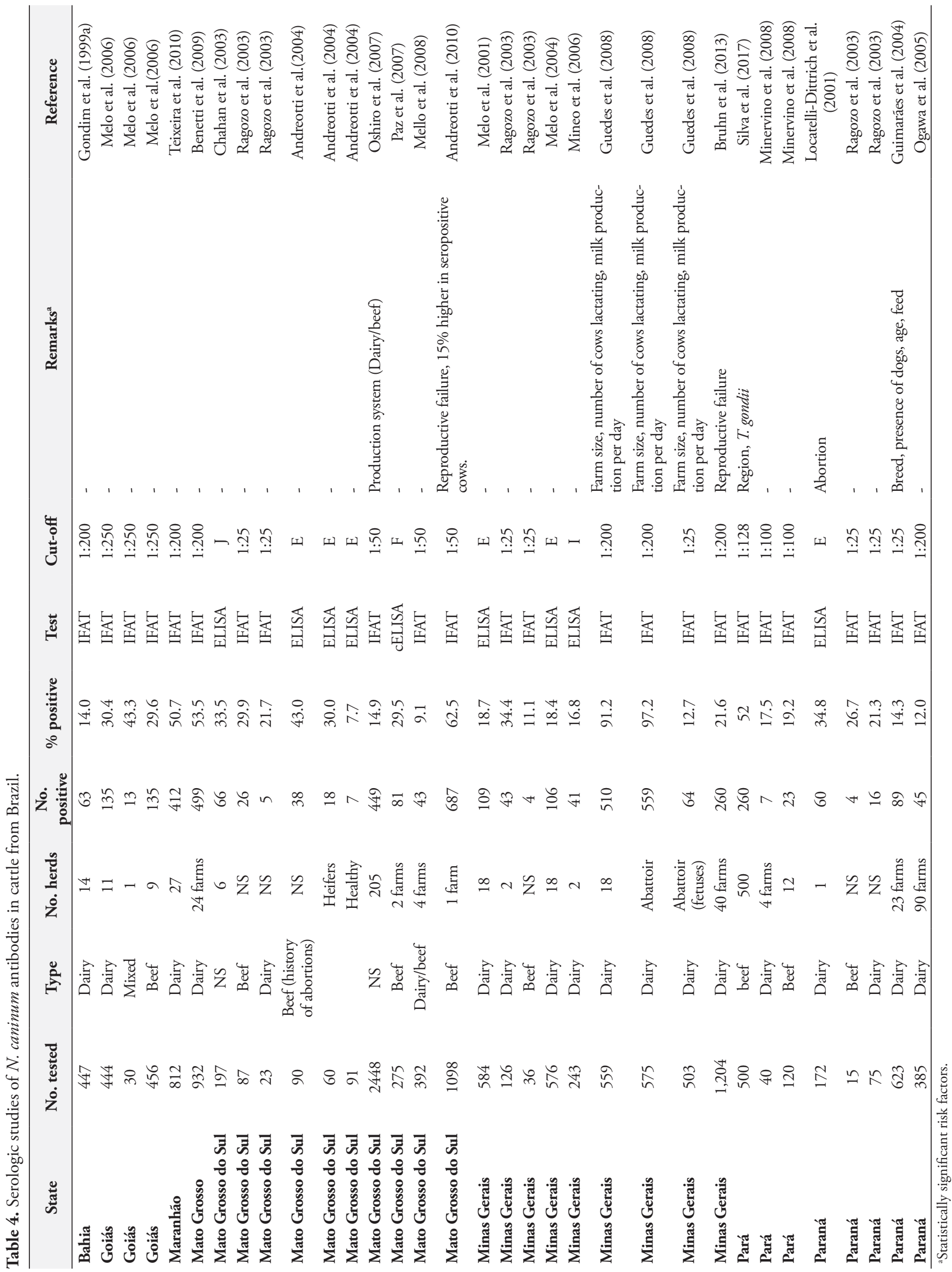




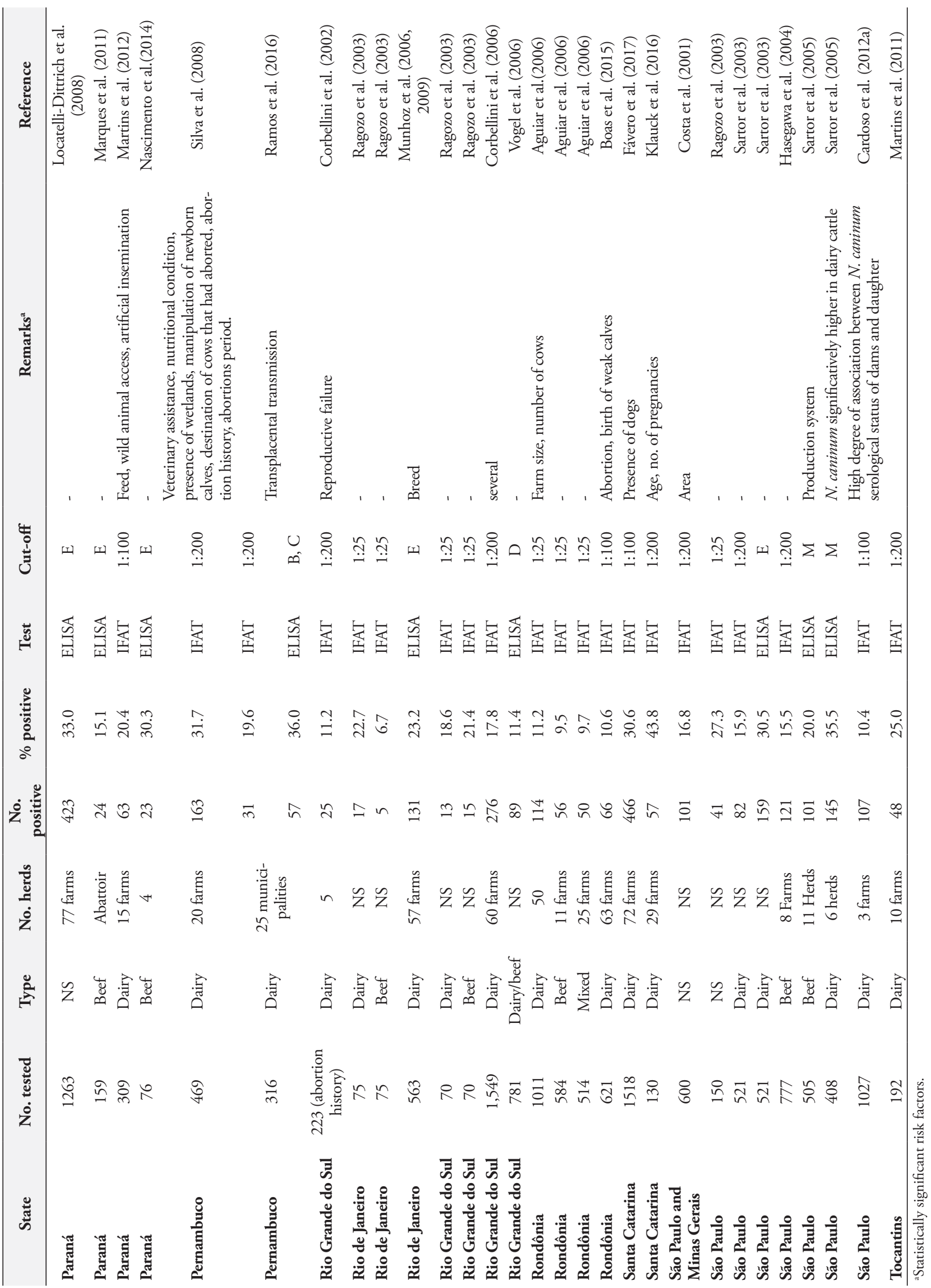


Table 5. Serological studies of $N$. caninum in buffaloes from Brazil.

\begin{tabular}{|c|c|c|c|c|c|c|c|}
\hline State & No. of farms & No. tested & No. positive & $\%$ positive & Test & Cut-off & References \\
\hline Bahia & 4 & 117 & 42 & 35.9 & IFAT & $1: 200$ & Gondim et al. (2007) \\
\hline Pará & 3 & 196 & 139 & 70.9 & IFAT & $1: 25$ & Gennari et al. (2005) \\
\hline Pará & 26 & 500 & 195 & 39 & IFAT & $1: 128$ & Silva et al. (2017) \\
\hline Pará & 4 & 212 & 187 & 88.2 & ELISA & $\mathrm{E}$ & Viana et al. (2009) \\
\hline Paraíba & 14 & 136 & 26 & 19.1 & IFAT & $1: 200$ & Brasil et al. (2015) \\
\hline Rio Grande do Sul & & 164 & 24 & 14.6 & ELISA & $\mathrm{D}$ & Vogel et al. (2006) \\
\hline \multirow{2}{*}{ Sáo Paulo } & \multirow{2}{*}{11} & \multirow{2}{*}{222} & 117 & 53.0 & NAT & $1: 40$ & \multirow{2}{*}{ Fujii et al. $(2001 \mathrm{a}, \mathrm{b})$} \\
\hline & & & 142 & 64.0 & IFAT & $1: 25$ & \\
\hline Sáo Paulo & 12 & 411 & 230 & 56.0 & IFAT & $1: 200$ & Souza et al. (2001) \\
\hline Sáo Paulo & 5 & 192 & 169 & 88.0 & IFAT & $1: 50$ & Chryssafidis et al. (2015) \\
\hline \multirow{2}{*}{ Northern Brazil-13 provinces } & & \multirow{2}{*}{4,796} & 2,665 & 55.5 & ELISA & G, H & \multirow{2}{*}{ Silva et al. (2014) } \\
\hline & & & 2,345 & 48.8 & IFAT & $1: 40$ & \\
\hline
\end{tabular}

Table 6. Serological studies of $N$. caninum in sheep from Brazil.

\begin{tabular}{|c|c|c|c|c|c|c|c|c|}
\hline State & Type & No. tested & No. positive & $\%$ positive & Test & Cut-off & Remarks & Reference \\
\hline Alagoas & 26 farms & 343 & 33 & 9.6 & IFAT & $1: 50$ & Small farms, water supply & $\begin{array}{l}\text { Faria et al. } \\
(2010)\end{array}$ \\
\hline $\begin{array}{l}\text { Federal } \\
\text { District }\end{array}$ & 32 farms & 1028 & 90 & 8.8 & IFAT & $1: 50$ & Titers up to 51,200 & $\begin{array}{l}\text { Ueno et al. } \\
\text { (2009) }\end{array}$ \\
\hline Maranháo & 5 farms & 64 & 3 & 4.7 & IFAT & $1: 25$ & $\begin{array}{l}\text { Food supplement, reproductive } \\
\text { failure }\end{array}$ & $\begin{array}{l}\text { Moraes et al. } \\
\quad(2011)\end{array}$ \\
\hline $\begin{array}{l}\text { Mato Grosso } \\
\text { do Sul }\end{array}$ & 1 farm & 441 & $\begin{array}{l}136 \\
141\end{array}$ & $\begin{array}{l}30.8 \\
32.0\end{array}$ & $\begin{array}{l}\text { IFAT } \\
\text { ELISA }\end{array}$ & $\begin{array}{l}1: 50 \\
A, L\end{array}$ & Comparison of techniques & $\begin{array}{l}\text { Andreot- } \\
\text { ti et al. (2009) }\end{array}$ \\
\hline Minas Gerais & 12 farms & 334 & 27 & 8.1 & IFAT & $1: 50$ & Abortion history & $\begin{array}{l}\text { Salaberry et al. } \\
\qquad(2010)\end{array}$ \\
\hline Minas Gerais & 2 farms & 155 & $\begin{array}{l}73 \\
41\end{array}$ & $\begin{array}{l}47.1 \\
26.4\end{array}$ & $\begin{array}{l}\text { IFAT } \\
\text { ELISA }\end{array}$ & $\begin{array}{l}1: 50 \\
A, C\end{array}$ & Age & $\begin{array}{l}\text { Rossi et al. } \\
\quad(2011)\end{array}$ \\
\hline Minas Gerais & 63 farms & 488 & 64 & 13.1 & IFAT & $1: 50$ & Age, area & $\begin{array}{l}\text { Andrade et al. } \\
\qquad(2012)\end{array}$ \\
\hline Paraná & 9 farms & 305 & 29 & 9.5 & IFAT & $1: 50$ & $\begin{array}{l}\text { Sex, age, breed, reproductive } \\
\text { fails, presence of dogs }\end{array}$ & $\begin{array}{l}\text { Romanel- } \\
\text { li et al. (2007) }\end{array}$ \\
\hline Pernambuco & 23 farms & 81 & 52 & 64.2 & IFAT & $1: 50$ & Age & $\begin{array}{l}\text { Tembue et al. } \\
\qquad(2011)\end{array}$ \\
\hline Pernambuco & $\begin{array}{c}\text { Rural } \\
\text { villages }\end{array}$ & 179 & 39 & 21.8 & IFAT & $1: 50$ & Region, age, sex, breed & $\begin{array}{l}\text { Arraes- } \\
\text { Santos et al. } \\
(2016)\end{array}$ \\
\hline Piauí & $\begin{array}{c}\text { Rural } \\
\text { villages }\end{array}$ & 153 & 8 & 5.2 & IFAT & $1: 50$ & Region, age, sex, breed & $\begin{array}{l}\text { Arraes- } \\
\text { Santos et al. } \\
(2016)\end{array}$ \\
\hline $\begin{array}{l}\text { Rio Grande } \\
\text { do Norte }\end{array}$ & 35 farms & 409 & 7 & 1.8 & IFAT & $1: 50$ & $\begin{array}{l}\text { Sex, presence of dogs, reproduc- } \\
\text { tive fails }\end{array}$ & $\begin{array}{l}\text { Soares et al. } \\
\text { (2009a) }\end{array}$ \\
\hline $\begin{array}{l}\text { Rio Grande } \\
\text { do Sul }\end{array}$ & 4 counties & 62 & 2 & 3.2 & ELISA & $\mathrm{D}$ & & $\begin{array}{l}\text { Vogel et al. } \\
\quad(2006)\end{array}$ \\
\hline Rondônia & 15 farms & 141 & 41 & 29.0 & IFAT & $1: 50$ & $\begin{array}{l}\text { Titers up to } 1: 25,600 \text {; Reproduc- } \\
\text { tive problems, presence of dogs, } \\
\text { source of water }\end{array}$ & $\begin{array}{l}\text { Aguiar et al. } \\
\text { (2004) }\end{array}$ \\
\hline São Paulo & $\begin{array}{l}\text { Meat } \\
\text { breeds }\end{array}$ & 597 & 55 & 9.2 & IFAT & $1: 50$ & Age and presence of dogs & $\begin{array}{l}\text { Figliuolo et al. } \\
\qquad(2004 \mathrm{a})\end{array}$ \\
\hline Sáo Paulo & 16 farms & 1497 & 120 & 8.0 & IFAT & $1: 25$ & $\begin{array}{l}\text { Water supply, presence of dogs, } \\
\text { reproductive problems }\end{array}$ & $\begin{array}{l}\text { Machado et al. } \\
\text { (2011) }\end{array}$ \\
\hline Sáo Paulo & 8 farms & 382 & 49 & 12.8 & IFAT & $1: 25$ & Tested for T. gondii & $\begin{array}{l}\text { Langoni et al. } \\
\qquad(2011)\end{array}$ \\
\hline $\begin{array}{l}\text { Sáo Paulo/ } \\
\text { Rio Grande } \\
\text { do Sul }\end{array}$ & Abattoir & 596 & 353 & 59.2 & IFAT & $1: 25$ & $\begin{array}{l}\text { Sex, breeding system, breed, } \\
\text { area, age }\end{array}$ & $\begin{array}{l}\text { Paiz et al. } \\
(2015)\end{array}$ \\
\hline
\end{tabular}

Bold=statistically significant risk factors. 
Table 7. Serological studies of antibodies to N. caninum in goats from Brazil.

\begin{tabular}{|c|c|c|c|c|c|c|c|c|}
\hline State & Type & No. tested & No. positive & $\%$ positive & Test & Cut-off & Remarks & Reference \\
\hline Bahia & 9 herds & 384 & 58 & 15.1 & IFAT & $1: 100$ & Breed & $\begin{array}{l}\text { Uzêda et al. } \\
\text { (2007b) }\end{array}$ \\
\hline Maranháo & 5 farms & 46 & 8 & 17.4 & IFAT & $1: 25$ & Reproductive failure & $\begin{array}{l}\text { Moraes et al. } \\
\qquad(2011)\end{array}$ \\
\hline Minas Gerais & 90 herds & 667 & 71 & 10.7 & IFAT & $1: 50$ & Maximum titer $1: 3,200$ & $\begin{array}{c}\text { Andrade et al. } \\
\qquad(2013)\end{array}$ \\
\hline Paraíba & Abattoir & 306 & 10 & 3.3 & IFAT & $1: 50$ & Gender & $\begin{array}{l}\text { Faria et al. } \\
\text { (2007) }\end{array}$ \\
\hline Pernambuco & 23 farms & 319 & 85 & 26.6 & IFAT & $1: 50$ & Age & $\begin{array}{l}\text { Tembue et al. } \\
\qquad(2011)\end{array}$ \\
\hline Pernambuco & Rural Villages & 174 & 5 & 2.9 & IFAT & $1: 50$ & Region, breed, age, sex & $\begin{array}{c}\text { Arraes- } \\
\text { Santos et al. } \\
(2016)\end{array}$ \\
\hline Piauí & Rural Villages & 202 & 4 & 2.0 & IFAT & $1: 50$ & Region, breed, age, sex & $\begin{array}{l}\text { Arraes- } \\
\text { Santos et al. } \\
(2016)\end{array}$ \\
\hline $\begin{array}{l}\text { Rio Grande do } \\
\text { Norte }\end{array}$ & 14 farms & 381 & 4 & 1.0 & IFAT & $1: 50$ & $\begin{array}{l}\text { Gender, reproductive fails, } \\
\text { presence of dogs }\end{array}$ & $\begin{array}{l}\text { Lima et al. } \\
\text { (2008) }\end{array}$ \\
\hline Santa Catarina & 57 cities & 654 & 30 & 4.6 & IFAT & $1: 50$ & Age, abortion, diet & $\begin{array}{l}\text { Topazio et al. } \\
\qquad(2014)\end{array}$ \\
\hline São Paulo & 19 farms & 394 & 25 & 6.4 & IFAT & $1: 50$ & $\begin{array}{l}\text { Maximum titer 1:12,800; } \\
\text { Age, presence of dogs }\end{array}$ & $\begin{array}{l}\text { Figliuolo et al. } \\
\text { (2004b) }\end{array}$ \\
\hline São Paulo & 17 farms & 923 & 161 & 17.7 & NAT & $1: 25$ & $\begin{array}{l}\text { Presence of dogs, Age, } \\
\text { gender, reproductive } \\
\text { problems }\end{array}$ & $\begin{array}{l}\text { Modolo et al. } \\
\qquad(2008)\end{array}$ \\
\hline
\end{tabular}

Bold=statistically significant risk factors.

Table 8. Serological studies of $N$. caninum antibodies in swine from Brazil.

\begin{tabular}{lcccccccc}
\hline \multicolumn{1}{c}{ State } & Type & $\begin{array}{c}\text { No. } \\
\text { tested }\end{array}$ & $\begin{array}{c}\text { No. } \\
\text { positive }\end{array}$ & $\begin{array}{c}\% \\
\text { positive }\end{array}$ & Test & Cut-off & Remarks & Reference \\
\hline Paraíba & Abattoir & 130 & 4 & 3.1 & IFAT & $1: 50$ & Sex, Also tested for T. gondii & $\begin{array}{c}\text { Azevedo et al. } \\
(2010)\end{array}$ \\
Paraíba & Abattoir & 190 & 6 & 3.2 & IFAT & $1: 50$ & Also tested for T. gondii & $\begin{array}{c}\text { Feitosa et al. } \\
(2014 b)\end{array}$ \\
Mato Grosso do Sul & Free living, wild & 83 & 9 & 10.8 & IFAT & $1: 50$ & Sex, age & Soares et al. (2016) \\
\hline
\end{tabular}

Bold=statistically significant risk factor.

Table 9. Serological studies of $N$. caninum in cats from Brazil.

\begin{tabular}{|c|c|c|c|c|c|c|c|c|}
\hline State & Type & $\begin{array}{l}\text { No. } \\
\text { tested }\end{array}$ & $\begin{array}{c}\text { No. } \\
\text { positive }\end{array}$ & $\begin{array}{c}\% \\
\text { positive }\end{array}$ & Test & Cut-off & Remarks & Reference \\
\hline Bahia & Indoor, outdoor & 272 & 8 & 2.9 & IFAT & $1: 50$ & Also tested Sarcocystis neurona & Meneses et al. (2014) \\
\hline Maranháo & Outdoor access & 200 & 54 & 27.0 & IFAT & $1: 25$ & Also tested $T$. gondii & Braga et al. (2012) \\
\hline $\begin{array}{l}\text { Mato Grosso } \\
\text { do Sul }\end{array}$ & $\begin{array}{l}\text { Free roaming and } \\
\text { domiciled }\end{array}$ & 151 & 10 & 6.6 & IFAT & $1: 50$ & $\begin{array}{l}\text { Also tested } T \text {. gondii and } L \text {. } \\
\text { infantum }\end{array}$ & Sousa et al. (2014) \\
\hline Paraíba & $\begin{array}{c}\text { Free roaming and } \\
\text { domiciled }\end{array}$ & 201 & 0 & 0.0 & IFAT & $1: 50$ & 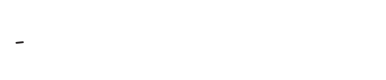 & Feitosa et al. (2014a) \\
\hline Pernambuco & Rural villages & 32 & 2 & 6.2 & IFAT & $1: 50$ & Region, breed, age, sex & $\begin{array}{c}\text { Arraes-Santos et al. } \\
\text { (2016) }\end{array}$ \\
\hline Piauí & Rural villages & 3 & 0 & 0.0 & IFAT & $1: 50$ & Region, breed, age, sex & $\begin{array}{l}\text { Arraes-Santos et al. } \\
\qquad(2016)\end{array}$ \\
\hline Sáo Paulo & $\begin{array}{l}\text { Free roaming and } \\
\text { domiciled }\end{array}$ & 502 & 60 & 11.9 & $\begin{array}{l}\text { NAT } \\
\text { IB }\end{array}$ & $\begin{array}{l}1: 40 \\
B, C\end{array}$ & $\begin{array}{l}\text { NAT + (1+ at } 1: 800) \\
10 \mathrm{IB}+ \\
\text { Also tested } S . \text { neurona }\end{array}$ & Dubey et al. (2002) \\
\hline Sáo Paulo & Domiciled & 400 & 98 & 24.5 & IFAT & $1: 16$ & $\begin{array}{l}4 \mathrm{IFAT}+ \\
1: 256\end{array}$ & Bresciani et al. (2007a) \\
\hline Sáo Paulo & Domiciled & 70 & 0 & 0.0 & IFAT & $1: 16$ & - & Coelho et al. (2011) \\
\hline
\end{tabular}


Table 10. Serological studies of $N$. caninum in wild animals from Brazil.

\begin{tabular}{|c|c|c|c|c|c|c|c|}
\hline Host species & Type & No. tested & No. positive & $\%$ positive & Test & Cut-off & Reference \\
\hline \multicolumn{8}{|l|}{ Fam. Felidae } \\
\hline Caracal (Caracal caracal) & Zoo & 1 & 1 & 100.0 & IFAT & $1: 25$ & André et al. (2010) \\
\hline Fishing cat (Prionailurus viverrinus) & Zoo & 1 & 1 & 100.0 & IFAT & $1: 25$ & André et al. (2010) \\
\hline \multirow{2}{*}{ Jaguar (Panthera onca) } & Wild & 11 & 7 & 63.6 & IFAT & $1: 25$ & Onuma et al. (2014) \\
\hline & Zoo & 13 & 8 & 61.5 & IFAT & $1: 25$ & André et al. (2010) \\
\hline $\begin{array}{l}\text { Jaguarundi (Puma yagouaroundi syn. } \\
\text { Herpailurus yagouaroundi) }\end{array}$ & Zoo & 25 & 5 & 20.0 & IFAT & $1: 25$ & André et al. (2010) \\
\hline Lion (Panthera leo) & Zoo & 9 & 1 & 11.1 & IFAT & $1: 25$ & André et al. (2010) \\
\hline $\begin{array}{l}\text { Little-spotted-cat (Leopardus } \\
\text { tigrinus) }\end{array}$ & Zoo & 35 & 11 & 31.4 & IFAT & $1: 25$ & André et al. (2010) \\
\hline Ocelot (Leopardus pardalis) & Zoo & 42 & 30 & 71.4 & IFAT & $1: 25$ & André et al. (2010) \\
\hline Pampas cat (Oncifelis colocolo) & Zoo & 3 & 3 & 100.0 & IFAT & $1: 25$ & André et al. (2010) \\
\hline Puma-cougar (Puma concolor) & Zoo & 18 & 5 & 27.8 & IFAT & $1: 25$ & André et al. (2010) \\
\hline Serval (Leptailurus serval) & Zoo & 1 & 1 & 100.0 & IFAT & $1: 25$ & André et al. (2010) \\
\hline Tiger (Panthera tigris) & Zoo & 6 & 4 & 66.7 & IFAT & $1: 25$ & André et al. (2010) \\
\hline \multicolumn{8}{|l|}{ Fam. Canidae } \\
\hline \multirow[t]{3}{*}{ Crab-eating fox (Cerdocyon thous) } & \multirow[t]{2}{*}{ Wild } & \multirow[t]{2}{*}{15} & 4 & 26.6 & IFAT & $1: 50$ & \multirow{2}{*}{$\begin{array}{l}\text { Cañón -Franco et al. } \\
\qquad(2004)\end{array}$} \\
\hline & & & 1 & 6.6 & NAT & $1: 40$ & \\
\hline & Captivity & 2 & 0 & 0.0 & IFAT & $1: 50$ & Melo et al. (2002) \\
\hline \multirow[t]{2}{*}{ Hoary fox(Pseudalopex vetulus) } & \multirow[t]{2}{*}{ Wild } & \multirow[t]{2}{*}{30} & \multirow[t]{2}{*}{0} & \multirow[t]{2}{*}{0.0} & IFAT & $1: 50$ & \multirow{2}{*}{$\begin{array}{l}\text { Cañón-Franco et al. } \\
\qquad(2004)\end{array}$} \\
\hline & & & & & NAT & $1: 40$ & \\
\hline Maned wolf (Chrysocyon brachyurus) & Captivity and wild & 48 & 0 & 0.0 & IFAT & $1: 50$ & Melo et al. (2002) \\
\hline \multirow{3}{*}{ Pampas fox (Lycalopex gymnocercus) } & Zoo and preserves & 59 & 5 & 8.5 & IFAT & $1: 25$ & Vitaliano et al. (2004) \\
\hline & \multirow[t]{2}{*}{ Wild } & \multirow[t]{2}{*}{12} & \multirow[t]{2}{*}{5} & \multirow[t]{2}{*}{41.6} & IFAT & $1: 50$ & \multirow{2}{*}{$\begin{array}{l}\text { Cañón-Franco et al. } \\
\qquad(2004)\end{array}$} \\
\hline & & & & & NAT & $1: 40$ & \\
\hline \multicolumn{8}{|l|}{ Fam. Didelphidae } \\
\hline Opossum (Didelphis marsupialis) & Feral & 396 & 84 & 21.2 & IFAT & $1: 25$ & Yai et al. (2003) \\
\hline \multicolumn{8}{|l|}{ Fam. Bovidae } \\
\hline Barbary sheep (Ammotragus lervia) & Zoo & 17 & 4 & 23.5 & IFAT & $1: 50$ & Morikawa et al. (2014) \\
\hline \multicolumn{8}{|l|}{ Fam. Cervidae } \\
\hline \multirow{2}{*}{$\begin{array}{l}\text { Brazilian dwarf brocket (Mazama } \\
\text { nana) }\end{array}$} & Captive and zoo & 40 & 7 & 17.5 & IFAT & $1: 50$ & Tiemann et al. (2005b) \\
\hline & Captive & 22 & 1 & 4.5 & ELISA & $\mathrm{E}$ & Zimpel et al. (2015) \\
\hline $\begin{array}{l}\text { Brown brocket deer (Mazama } \\
\text { gouazoubira) }\end{array}$ & Captive and zoo & 66 & 29 & 43.9 & IFAT & $1: 50$ & Tiemann et al. (2005b) \\
\hline Marsh deer (Blastoceros dichotomus) & Captive & 6 & 1 & 16.7 & ELISA & $\mathrm{E}$ & Zimpel et al. (2015) \\
\hline \multirow{2}{*}{ Pampas deer (Ozotoceros bezoarticus) } & Wild National Park & 23 & 3 & 13.0 & IFAT & $1: 50$ & Tiemann et al. (2005a) \\
\hline & Pantanal & 16 & 12 & 75.0 & IFAT & $1: 50$ & \\
\hline Red brocket deer (Mazama & $\begin{array}{l}\text { Captive } \\
\text { PR }\end{array}$ & 4 & 0 & 0.0 & ELISA & E & Zimpel et al. (2015) \\
\hline & Captive and zoo & 29 & 18 & 62.0 & IFAT & $1: 50$ & Tiemann et al. (2005b) \\
\hline Rodon (Mazama rondoni) & Captive and zoo & 8 & 3 & 37.5 & IFAT & $1: 50$ & Tiemann et al. (2005b) \\
\hline Small red brocket (Mazama bororo) & Captive and zoo & 3 & 2 & 66.6 & IFAT & $1: 50$ & Tiemann et al. (2005b) \\
\hline Fam. Caviidae & & & & & & & \\
\hline & Wild & 213 & 20 & 9.4 & IFAT & $1: 25$ & Yai et al. (2008) \\
\hline Capybaras (Hydrochaeris & Wild & 63 & 1 & 1.5 & IFAT & $1: 25$ & Valadas et al. (2010a) \\
\hline & Wild & 170 & 0 & 0.0 & IFAT & $1: 50$ & Abreu et al. (2016) \\
\hline
\end{tabular}


Table 11. Serological studies of $N$. caninum antibodies in horses from Brazil.

\begin{tabular}{|c|c|c|c|c|c|c|c|c|}
\hline State & $\begin{array}{l}\text { No. } \\
\text { tested }\end{array}$ & Type & $\begin{array}{c}\text { No. } \\
\text { positive }\end{array}$ & $\%$ positive & Assay & $\begin{array}{c}\text { Cut-off titer } \\
\text { or test }\end{array}$ & Remarks & Reference \\
\hline Mato Grosso & 200 & Healthy & 30 & 15.0 & IFAT & $1: 50$ & $\begin{array}{l}\text { Highest titer } 1: 400 \text { in } \\
1 \text { horse. }\end{array}$ & $\begin{array}{l}\text { Laskoski et al. } \\
\qquad(2015)\end{array}$ \\
\hline Pará & 411 & Healthy horses & 28 & 6.8 & IFAT & $1: 50$ & $\begin{array}{l}\text { No risk factors } \\
\text { detected. }\end{array}$ & $\begin{array}{c}\text { Norlander } \\
(2014)\end{array}$ \\
\hline Paraná & 72 & Mares & 28 & 38.8 & IFAT & $1: 50$ & $\begin{array}{l}2 \text { foals had } \\
\text { pre-colostral antibodies }\end{array}$ & $\begin{array}{l}\text { Locatelli- } \\
\text { Dittrich et al. } \\
\quad(2006)\end{array}$ \\
\hline Paraná & 14 & Pregnant mares & 12 & 85.7 & IFAT & $1: 50$ & Highest titer 1:400 & $\begin{array}{l}\text { Hoffmann } \\
\text { Kormann et al. } \\
\text { (2008) }\end{array}$ \\
\hline Paraná & 97 & Healthy horses & 14 & 14.4 & IFAT & $1: 50$ & $\begin{array}{l}\text { Highest titer 1:200 in } \\
2 \text { horses }\end{array}$ & $\begin{array}{c}\text { Villalobos et al. } \\
\text { (2012) }\end{array}$ \\
\hline $\begin{array}{l}\text { Paraná and Santa } \\
\text { Catarina }\end{array}$ & 112 & $\begin{array}{l}\text { Mares from } 5 \\
\text { breeding farms }\end{array}$ & 14 & 12.5 & IFAT & $1: 50$ & $\begin{array}{l}25.7 \%(9 / 35) \\
\text { prevalence in mares } \\
\text { with reproductive } \\
\text { problem versus } \\
6.4 \%(5 / 77) \text { without } \\
\text { problems. Highest titer } \\
\text { only 1:50. }\end{array}$ & $\begin{array}{l}\text { Abreu et al. } \\
\text { (2014) }\end{array}$ \\
\hline Rio Grande do Sul & 241 & $\begin{array}{l}\text { Cart horses and } \\
\text { Crioula breed }\end{array}$ & 34 & 15.9 & IFAT & $1: 50$ & - & $\begin{array}{l}\text { Toscan et al. } \\
\text { (2011) }\end{array}$ \\
\hline Rio Grande do Sul & 181 & Pregnant mares & 39 & 21.5 & ELISA & $\mathrm{A}, \mathrm{C}$ & $\begin{array}{l}9.3 \% \text { of their paired } \\
\text { foals had pre-colostral } \\
\text { anti-Neospora } \\
\text { antibodies. }\end{array}$ & $\begin{array}{l}\text { Pivoto et al. } \\
\quad(2014)\end{array}$ \\
\hline Rio Grande do Sul & 197 & Abattoir & 77 & 39.1 & IFAT & $1: 50$ & $\begin{array}{l}\text { Tested for Sarcocystis } \\
\text { spp. and T. gondii }\end{array}$ & $\begin{array}{l}\text { Portella et al. } \\
\qquad(2017)\end{array}$ \\
\hline $\begin{array}{l}\text { Rio Grande do Sul, } \\
\text { Sáo Paulo, Rio de } \\
\text { Janeiro }\end{array}$ & 101 & Race horses & 0 & 0.0 & NAT & $1: 25$ & - & $\begin{array}{c}\text { Dubey et al. } \\
\text { (1999) }\end{array}$ \\
\hline Santa Catarina & 615 & Healthy & 25 & 4.1 & IFAT & $1: 50$ & $\begin{array}{l}72 \text { with history of } \\
\text { neurological and } \\
\text { reproductive problems. }\end{array}$ & $\begin{array}{l}\text { Moura et al. } \\
\text { (2013) }\end{array}$ \\
\hline Sáo Paulo & $\begin{array}{l}325 \\
483\end{array}$ & $\begin{array}{l}\text { Healthy } \\
\text { Diseased }\end{array}$ & $\begin{array}{l}19 \\
73\end{array}$ & $\begin{array}{c}5.8 \\
15.1\end{array}$ & IFAT & $1: 50$ & Highest titer $1: 400$ & $\begin{array}{l}\text { Villalobos et al. } \\
\qquad(2006)\end{array}$ \\
\hline Sáo Paulo & 26 & History of ataxia. & 15 & 57.6 & IFAT & $1: 2$ & $\begin{array}{l}26 \text { cerebrospinal fluids } \\
\text { negative. }\end{array}$ & $\begin{array}{l}\text { Stelmann et al. } \\
\text { (2011) }\end{array}$ \\
\hline South & 203 & Mares & 129 & 63.3 & IFAT & $1: 50$ & $\begin{array}{l}\text { Of } 129,34.8 \% \text { gave } \\
\text { birth to seropositive } \\
\text { foals. }\end{array}$ & $\begin{array}{l}\text { Antonello et al. } \\
\qquad(2012)\end{array}$ \\
\hline 10 states & 961 & $\begin{array}{l}\text { Old horses from } \\
\text { abattoirs }\end{array}$ & 24 & 2.5 & ELISA & $\mathrm{C}, \mathrm{K}$ & - & $\begin{array}{l}\text { Hoane et al. } \\
\text { (2006) }\end{array}$ \\
\hline
\end{tabular}

Table 12. Detection of $N$. caninum antibodies in avian species from Brazil.

\begin{tabular}{|c|c|c|c|c|c|c|}
\hline Host & Tested & \%positive & DNA or Antibodies & Test & Cut-off / Method & Reference \\
\hline \multirow{5}{*}{$\begin{array}{l}\text { Chicken (Gallus gallus } \\
\text { domesticus) }\end{array}$} & 200 (outdoor) & $47(23.5)$ & Antibodies & IFAT & $1: 50$ & \multirow{3}{*}{ Costa et al. (2008) } \\
\hline & 200 (indoor) & $3(1.5)$ & Antibodies & IFAT & $1: 50$ & \\
\hline & 10 positive & $6(60.0)$ & DNA & PCR & $\begin{array}{c}\text { 3/4 of brain Direct PCR } \\
\text { for Nc5 }\end{array}$ & \\
\hline & \multirow{2}{*}{100 farm chickens } & $17(17.0)$ & Antibodies & IFAT & $1: 50$ & \multirow{2}{*}{$\begin{array}{l}\text { Gonçalves et al. } \\
\text { (2012) }\end{array}$} \\
\hline & & $6(6.0)$ & DNA & PCR & $\mathrm{Np} 21 / \mathrm{Np} 6$ & \\
\hline Sparrow (Passer domesticus) & 40 & $3(7.5)$ & DNA & PCR & $\begin{array}{l}\text { Heart and brain. } \\
\text { Nested PCR of Nc5 and } \\
\text { sequencing of ITS }\end{array}$ & $\begin{array}{l}\text { Gondim et al. } \\
\qquad(2010)\end{array}$ \\
\hline Several species & 294 & $0(0.0)$ & Antibodies & IFAT & $1: 50$ & Mineo et al. (2011) \\
\hline
\end{tabular}


In one survey, 802 serum samples of female cattle from 55 dairy and beef farms from six Brazilian states (SP, RJ, MG, PR, RS, MS) were assayed by IFAT (cut-off 1:25) and 23.6\% were seropositive; association between positivity to $N$. caninum and state of origin, age and production purpose was analyzed using uniform methodology (RAGOZO et al., 2003). Although seroprevalence was higher in animals older than 24 months, this difference was not statistically significant. Conclusion is not definitive because of the selection of low cut-off of 1:25. Among the six states, RJ had the lowest prevalence and MG the highest and dairy cattle had higher prevalence than beef cattle. In another large study from MS, $N$. caninum antibodies were found in cattle from 143 of 205 herds (IFAT 1:50); the cows were older than two years (OSHIRO et al., 2007). Overall seroprevalence was $14.9 \%$ (Table 4).

Even after using a higher cut-off titer (IFAT 1:200) than used most of the surveys listed in Table 4, high prevalence were recorded from MG, where $N$. caninum antibodies were detected in 23 of 24 herds with individual seroprevalence of $21.6 \%$ (BRUHN et al., 2013); and MT, where antibodies to N. caninum were found in $499(53.5 \%)$ of 932 cattle samples, with at least one positive in each farm (BENETTI et al., 2009). In another report from MG, very high $(91.2 \% ; 510 / 559)$ prevalence of antibodies to $N$. caninum was found among 18 farms (GUEDES et al., 2008), revealing that $N$. caninum is well spread in the southern region of the state. They also recorded $97.2 \%$ (559/575) prevalence in cows from an abattoir.

There is an unconfirmed report that the quality of milk might be affected by neosporosis (MELO et al., 2001); an association was reported between the type of milk, classified as A, B and C according to its quality, produced in the farms and positivity to $N$. caninum antibodies, with higher occurrence in farms of MG that produce milk grade A/B than grade $\mathrm{C}$; and the authors discussed about the production technology used indifferent farms, animals stress and commercialization. One possible cause is that the production of types A/B milk is higher and requests more from the animals, generating stress, which could be responsible for the higher prevalence.

An association between seroprevalence and age of cattle (older animals presenting higher prevalence) was detected, while feed produced on the farm was negatively associated with $N$. caninum infection in PR (GUIMARÁES et al., 2004). Also in PR, production of food in the farm, absence of artificial insemination and access of domestic and wild animals to feed facilities were associated with infection (MARTINS et al., 2012).

A strong association of $N$. caninum infection was found in farms of RS, which had presence of dogs close to the livestock and which also fed calves with colostrum pooled from several cows (CORBELLINI et al., 2006). In this study, the size of the farm was inversely associated with the presence of positive animals.

An association between beef herds and infection by N. caninum was reported in the Amazon region, $\mathrm{RO}$, while comparing beef, dairy and mixed herds (AGUIAR et al., 2006). In that region, farms with more than 25 animals were also a risk factor. However, reproductive problems, contact with forest areas and presence of dogs were not associated with the coccidian infection.
Significant association related to animal management was found in PE (SILVA et al., 2008). Veterinary assistance, nutritional status, presence of wetlands, manipulation of the newborn calves (use of gloves when handling aborted fetuses), and destination of cows that aborted (higher in the ones that were treated with antibiotics than the ones that were discarded) were risk factors for the infection.

Pure bred Holstein cows had a higher exposure rate than mixed breeds (MUNHOZ et al., 2009) and an association between reproductive abnormalities (Table 4) (repeated estrus, repeated miscarriages and temporary anestrus) and seropositivity to $N$. caninum has been reported (BRUHN et al., 2013).

$N$. caninum is considered a primary pathogen and not influenced by concurrent BHV1, BVDV infections in dairy herds (MELO et al., 2004; MINEO et al., 2006).

Antibodies can fluctuate during pregnancy as reported, and increase in titer is not always associated with abortion (CARDOSO et al., 2009). A prospective longitudinal study was carried out in three farms in SP, during two consecutive years and the reproductive parameters were analyzed in those herds (CARDOSO et al., 2012a). In only one of the three herds the relative risk of abortion between $N$. caninum positive and negative cows was higher in the positive animals. No difference was observed regarding gestational age at abortion, repeated abortion, number of inseminations, and calving interval. A high association between $N$. caninum serological status of dams and daughters were observed in a longitudinal study carried out in three farms from SP, confirming the importance of vertical transmission, but there was no difference in the culling rate between positive and negative cows (CARDOSO et al., 2012b). A significant relationship between seropositivity of cattle and their offspring was also found in PE (RAMOS et al., 2016), which had a rate of transplacental transmission of $72.2 \%(13 / 18)$ for adults and $69.2 \%(9 / 13)$ for heifers by IFAT and $43.5 \%$ (17/39) for adults and 50.0\% (9/18) for heifers by ELISA, concluding that vertical transmission is the major form of infection in this region.

Buffaloes: Studies with serum samples from Brazilian buffaloes (Table 5) showed occurrence of $N$. caninum antibodies varying from $14.6 \%$ to $88 \%$. However, despite the high occurrence values, no reproductive disorders were reported in those groups (FUJII et al., 2001a, b; GENNARI et al., 2005; GONDIM et al., 2007)

Sheep: Seroprevalences ranged from $1.8 \%$ to $64.2 \%$ (Table 6). Some surveys stated as risk factors: abortion in the flock, presence of dogs, extensive husbandry systems and breed of the sheep. Great part of the studies also evaluated the presence of $T$. gondii infection, which usually showed a higher prevalence. In 2017, Filho et al. (2017) studied the vertical transmission rate of 50 naturally infected sheep, analysed by in house ELISA for six months. The initial prevalence of infection was 26.0\% $(13 / 50)$ and by the end of the study it had increased to $72 \%(36 / 50)$, being the vertical transmission rate $11 \%$, which one sheep out of nine from a group gave birth to two infected ewes (IFAT 1:25).

Goats: In goats, serological surveys found rates between $1.0 \%$ (LIMA et al., 2008) to 26.6\% (TEMBUE et al., 2011) of prevalence (Table 7). A study to evaluate infections by $T$. gondii, $N$. caninum and caprine arthritis-encephalitis virus (CAEV) was conducted, finding a prevalence of $37.81 \%, 23.62 \%$ and $17.23 \%$, 
respectively (COSTA et al., 2012). The results indicate that CAEV does not predispose goats to infection by $T$. gondii or $N$. caninum. However, when CAEV/T. gondii or CAEV/ N. caninum infection were detected, occurrence of reproductive failure was higher, maybe related to poor husbandry conditions. Differential diagnosis in cases of abortions in small ruminants is highly desirable.

Also, N. caninum DNA was found in brains of goats from BA. Silva et al. (2009) analyzed brains, hearts and tongues of 102 goats from slaughterhouses, and found a frequency of 1,96\% (2/102), using primers for ITS-1 region (JS4/CT2b; CT1/CT2).

Pigs: The prevalence of anti- $N$. caninum antibodies is low in pigs, and further studies are needed to evaluate the role of this species in the epidemiology of the parasite, including attempts to isolate viable parasites. Table 8 summarizes the studies with pigs from Brazil.

N. caninum antibodies were also found in feral pigs (Sus scrofa) in $10.8 \%(9 / 83)$ of samples from Pantanal, MS, with titers up to 1:800 by IFAT (SOARES et al., 2016).

Cats: In Brazil, studies determining the prevalence of antibodies in serum of cats (Table 9) found results that range from $0 \%$, in cats from Andradina, SP, and Patos, PB (COELHO et al., 2011; FEITOSA et al., 2014a) to $27 \%$ in cats from MA (BRAGA et al., 2012). In animals from SP, NAT antibodies were found in 60 of 502 (12\%) (DUBEY et al., 2002). The samples with titers greater than 1:80 were also examined by IB, as a confirmatory test, being ten of the 24 cats $(41.6 \%)$ positive for both tests.

Wild animals: $N$. caninum antibodies were detected in sera of wild animals kept in captivity or trapped in the wild of the Families: Canidae, Felidae, Didelphidae, Bovidae, Caviidae and Cervidae (Table 10).

Among wild herbivores, Neospora has been better documented in cervids from Pantanal region (MS) (TIEMANN et al., 2005a). In that study, serum samples from 23 pampas deer (Ozotoceros bezoarticus) from the National Park of Emas, in GO, and 16 captured in bovine's farms, from Pantanal region, in MT, were tested for the presence of $N$. caninum antibodies. They found $13 \%$ and $75 \%$ positivity, respectively, for the deer that live inside the park and the ones from Pantanal, which is close to farms indicating that this proximity of wild and domestic animals could increase the occurrence of $N$. caninum infection among deer. From the Zoo of Curitiba, PR, 17 samples from Barbary sheep (Ammotragus lervia), from the Bovidae Family, were examined and four (23.5\%) presented $N$. caninum antibodies (MORIKAWA et al., 2014).

Yai et al. (2003) tested 396 feral opossums (Didelphis marsupialis) samples from different regions of the city of São Paulo, and 21.2\% (84/396) were positive.

Sera from 14 species of wild felids from zoos were tested for the presence of $N$. caninum (Table 10) antibodies and 12 species had at least one positive animal (ANDRÉ et al., 2010). In addition, 11 serum samples from free range jaguars (Panthera onca) from Pantanal were examined and seven $(63.6 \%)$ were positive (ONUMA et al., 2014). In both studies, IFAT with a cut-off of $1: 25$ and anti-cat commercial conjugate was used for IgG antibody determination.

Despite the importance of wild canids in the epidemiology of $N$. caninum, few studies are available in Brazil. Crab-eating fox (Cerdocyon thous) is one of most common canids of South America,
(Gennari, own observations) and four of these foxes were fed with masseter muscle and brain of two $N$. caninum seropositive bovines (IFAT >200). The foxes received the inoculum in two consecutive days. Two animals excreted Hammondia heydorni oocysts on eight and nine dpi but not Neospora oocysts (SOARES et al., 2009b). By means of molecular techniques, Nascimento et al. (2015) identified N. caninum in brain of six from 49 (12.2\%) hoary foxes (Pseudalopex vetulus syn. Lycalopex vetulus) from PB. The molecular identification of the amplified products by sequencing reaction, using Nc-5 gene, presented $99 \%$ similarity with $N$. caninum.

Similarly, Muradian et al. (2012) tested wild urban rodents tissues (Family Muridae), but did not detect $N$. caninum DNA in four mice (Mus musculus), 20 brown rats (Rattus novergicus), and 193 black rats (Rattus rattus) from São Paulo city. Regarding capybaras, the first study done (YAI et al., 2008) tested animals from 11 counties in SP by IFAT (1:25) and found a prevalence of $9.4 \%(20 / 213)$, suggesting that they can serve as a source of $N$. caninum infection for wild canids. Also in SP, 63 capybaras were examined for $N$. caninum by IFAT (1:25) and other diseases and found two positive animals and one of them was positive for both $T$. cruzi and $N$. caninum, but no association was observed (VALADAS et al., 2010a). Recently, 170 samples of capybaras from SP were analyzed, but none were positive, although 17 (10\%) were positive for $T$. gondii (ABREU et al., 2016). DNA of $N$. caninum was found in capybaras from PR (TRUPPEL et al., 2010), in $23 \%(6 / 26)$ of the studied animals. Parasite DNA, aiming the Nc5 gene was found in the liver and lymph nodes and ITS-1 was found in blood, liver, heart and lymph nodes.

Horses: At present, it is uncertain if horses are infected with both $N$. caninum and $N$. hughesi (DUBEY et al., 2017). Serosurveys on horses conducted in Brazil are summarized in Table 11. N. caninum antigen was used in all studies with exception of Hoane et al. (2006), that used $N$. hughesi SAG1 (NhSAG1) in an in-house ELISA.

A low rate of infection $(0.4 \%$, IFAT $1: 100)$ was found among 500 donkeys (Equus asinus) sampled in BA; positive cases were confirmed by IB (GALVÃO et al., 2015). In a previous limited survey carried out in PA, no seropositive donkeys $(n=6)$ or mules $(n=9)$ were found (NORLANDER, 2014). Recently, a $2 \%$ seroprevalence was reported in donkeys $(n=333)$ from five northeastern states (AL, PB, PE, PI and RN) using IFAT (1:50). In all these studies, $N$. caninum $\mathrm{NC}-1$ strain was used as antigen source (GENNARI et al., 2016).

In PR, antibodies to Neospora were detected in two foals (LOCATELLI-DITTRICH et al., 2006), but the information is not definitive because of the low titer (1:50) detected. In addition, Antonello et al. (2012), by IFAT (1:50, N. caninum antigen), reported a high prevalence $(63.3 \%)$ of Neospora antibodies in sera of 203 thoroughbred mares and their foals before suckling in two farms from Southern Brazil. A high percentage (34.8\%) of seropositive mares gave birth to seropositive foals. Additionally, $8 \%$ of seronegative mares gave birth to seropositive foals. Mare sera were titrated further to 1:200 dilution and the seropositivity decreased to $33 \%$, but foal sera were not titrated. In another study performed in RS, Neospora antibodies were found in $21.5 \%$ of 181 mares and in $9.3 \%$ of their foals in pre-suckling sera (PIVOTO et al., 2014); in this case, antibodies were assayed using an in-house indirect 
ELISA, with NC-1 strain and soluble protein from tachyzoites maintained in CV-1 cells as antigen. Low levels of maternal IgG can cross the placenta in mares. Therefore, further studies are needed to confirm results of these investigations from Brazil (DUBEY et al., 2017).

Avian species: Table 12 summarizes the surveys of detection of $N$. caninum antibodies detection in avian species from Brazil. Seroprevalence was higher in free range chickens; $23.5 \%$ of 200 outdoors and $1.5 \%$ of 200 indoors chickens (Gallus gallus), in BA were seropositive (COSTA et al., 2008). In the same study, the authors found positive results for PCR from 6/10 (60\%) seropositive chickens. 40 of 293 wild sparrows (Passer domesticus) from BA and PE were seropositive and $N$. caninum DNA by PCR was detected in three (7.5\%) of brain and heart from 40 animals (GONDIM et al., 2010).

In a study by serological and histological methods none of the 294 wild and captive birds from nine avian orders had $N$. caninum antibodies. However in two psittacine birds, Apicomplexa-like tissue cysts were found and were immunostained positive with $N$. caninum antisera (MINEO et al., 2011).

Results of the experimental infection in birds from Brazil are summarized in Table 13. In the first Brazilian study (FURUTA et al., 2007) 50 chickens were inoculated with $N$. caninum tachyzoites, using different doses; chickens seroconverted but remained healthy. In 15 euthanized chickens, $N$. caninum tachyzoites were reported to be present in different tissues by IHC, at $15 \mathrm{dpi}$; however, no illustrations were provided. At the termination of the experiment (60 dpi), all chickens were seronegative by IFAT $(<1: 20) N$. caninum was not found by IHC. In laying hens, no evidence of vertical transmission was found. However, $50 \%$ of embryonated chicken eggs inoculated with $N$. caninum died and chickens that hatched $21 \mathrm{dpi}$ had neurological signs. Dogs fed chorioallantoid membranes and whole infected eggs seroconverted and excreted $N$. caninum oocysts in their feces, as confirmed by PCR (Nc5) (FURUTA et al., 2007).

In an unconfirmed report, four littermate two-month old dogs fed with chorioallantoid membranes previously infected in ovo with $10^{6} \mathrm{NC}-1$ strain tachyzoites were euthanized 3, 4, 5 and $6 \mathrm{dpi}$ (MUNHOZ et al., 2013). The authors reported immunoreactivity to $N$. caninum in lesions in lungs, spleen, and small and large intestine but strangely $N$. caninum DNA was not detected in affected tissues by conventional PCR. The gross lesions depicted resemble bacterial septicemia and the results need confirmation. The dogs did not excrete oocysts. In a follow up study, the authors, infected 90-days old chickens and embryonated eggs with $10^{6} \mathrm{~N}$. caninum tachyzoites using NC-1 strain and fed three dogs with infected organs but the dog did not excrete oocysts (MUNHOZ et al., 2014). Although there is no confirmation by IHC and microscopy, $N$. caninum DNA was found in the spleen and pectoral muscles of one of the birds born from the inoculated eggs (MUNHOZ et al., 2014).

An attempt to infect quails $(n=58)$ with doses of $3.5 \times 10^{6}$ and $5 \times 10^{6}$ of $N$. caninum tachyzoites (NC-Bahia) was largely unsuccessful (OLIVEIRA et al., 2013). Although there was evidence of transitory infection (seroconversion and finding of parasite DNA) at $14 \mathrm{dpi}$, the quails became seronegative at $30 \mathrm{dpi}$ with no demonstrable parasite DNA or antigen in their tissues; two dogs fed quail tissues did not excrete oocysts.

Experimental infection was also conducted in pigeons (Columba livia) inoculated with the $10^{7} \mathrm{NC}-1$ tachyzoites (MINEO et al., 2009). The pigeons developed transitory $N$. caninum antibodies starting at $5 \mathrm{dpi}$ but at the end of the experimental period of

Table 13. Detection of $N$. caninum in avian from experimental studies in Brazil.

\begin{tabular}{|c|c|c|c|c|c|}
\hline Host & No. animals & Dose & Tests & Results & Reference \\
\hline \multicolumn{6}{|l|}{ Chickens } \\
\hline \multirow{5}{*}{ (Gallus gallus domesticus) } & 7-days old & $10^{3}, 10^{4}, 10^{5}, 10^{6}$ & Killed 15,30,45,60 dpi & $\begin{array}{l}\text { No mortality; Dpi } \\
\text { 15:IFAT+ IHC+ }\end{array}$ & \multirow[t]{3}{*}{ Furuta et al. (2007) } \\
\hline & Laying eggs & $10^{8}$ & $\begin{array}{l}\text { Bioassay, PCR, } \\
\text { Histopathology }\end{array}$ & Dpi 60: IFAT - IHC - & \\
\hline & Embrionated eggs & $10^{3}, 10^{4}, 10^{5}, 10^{6}$ & $\begin{array}{l}\text { Histopathology Dogs } \\
\text { bioassay }\end{array}$ & $\begin{array}{l}\text { Eggs- Mortality: } \\
\text { 18-21 days incubation } \\
\text { Dogs shed oocyst }\end{array}$ & \\
\hline & 90-days old & $3 \times 10^{6}$ & $\begin{array}{c}\text { IFAT, IHC, } \\
\text { Histopathology, Bioassay }\end{array}$ & IFAT + & $\begin{array}{l}\text { Munhoz et al. } \\
\text { (2014) }\end{array}$ \\
\hline & Embrionated eggs & $1 \times 10^{2}$ & 2 embryos died & $\begin{array}{c}\text { PCR+ spleen, muscles } \\
\text { (1bird) }\end{array}$ & \\
\hline \multicolumn{6}{|l|}{ Pigeons } \\
\hline \multirow[t]{2}{*}{ (Columbia livia) } & 4 & $\begin{array}{l}1 \times 10^{7} \text { Blood samples } \\
\text { each } 5 \text { days }\end{array}$ & IFAT & $1: 20$; peak $10-20 \mathrm{dpi}$ & \multirow[t]{2}{*}{ Mineo et al. (2009) } \\
\hline & 4 & control & $\mathrm{IHC}+$ & Lungs, heart, CNS & \\
\hline \multicolumn{6}{|l|}{ Quails } \\
\hline (Coturnix coturnis & 40 & $3.5 \times 10^{6}$ & Histopathology & + & $\begin{array}{l}\text { Oliveira et al. } \\
\text { (2013) }\end{array}$ \\
\hline \multirow[t]{2}{*}{ japonica) } & 8 & $5.0 \times 10^{6}$ & IHC & + & \\
\hline & 10 & control & PCR & + & \\
\hline
\end{tabular}


45 days, all birds were seronegative. One infected pigeon died at $25 \mathrm{dpi}$ and $N$. caninum and lesions were found by IHC in lungs, heart, central nervous system, liver, spleen and kidney.

Rezende-Gondim et al. (2017) cultivated $N$. caninum, using a chicken cell line, and temperatures between $39^{\circ} \mathrm{C}$ and $41.5^{\circ} \mathrm{C}$. Multiplication of $N$. caninum tachyzoites in vitro was inhibited at temperatures similar to those of chickens. The authors concluded that the avian body temperatures may be one of the reasons that isolation of the parasite is difficult in avian species.

In summary, avians are a poor host for $N$. caninum, based on failure to isolate viable parasite from naturally infected tissues and failure to induce chronic infection in experimentally infected birds.

\section{Clinical infections}

Dogs: There are two confirmed reports of clinical neosporosis in adult dogs. A seven-year-old male Collie from Salvador, BA developed incoordination and rear limb paralysis (GONDIM et al., 2001). The dog was found to have a $N$. caninum IFAT titer of 1:1600. In spite of medication with Clindamycin $(22 \mathrm{mg} / \mathrm{kg})$ for 14 days the dog died. A necropsy was performed. Histologically there was encephalitis associated with tachyzoites and tissue cysts and the diagnosis was confirmed by IHC examination. Live tissue cysts were found in squash preparations from the dog brain. Tissue cysts were found in the brains of gerbils inoculated with brain homogenate of the dog. Viable $N$. caninum was propagated in cell cultures seeded with infected gerbil brain.

The second case was from a 10 year old dog from RS (MANN et al., 2016). Persistent dermal lesions with multifocal ulcerative nodules on the neck and pelvic limbs were observed. The dog had an IFAT $N$. caninum antibody titer of 1:6400. Cytological examination of the exudates from nodules showed pyogranulomatous inflammation with tachyzoites and $N$. caninum was identified by PCR. The dog was medicated with Clindamycin $(6 \mathrm{mg} / \mathrm{kg})$ for 28 days with resolvement of lesions. However, the dermal lesions with identifiable tachyzoites reappeared 12 days after the cessation of treatment, perhaps due to a very low dose of Clindamycin used; the usual treatment is $20-25 \mathrm{mg} / \mathrm{kg}$.

In addition to these confirmed reports, Langoni et al. (2012) isolated $N$. caninum by bioassay in gerbils inoculated with brains of two of seven dogs with neurological disorders. No other details were given about these dogs or the strain of Neospora, therefore, not included in Table 1 .
Cattle: Reports of confirmed neosporosis abortion from six states are summarized in Table 14. Apparently, all of these cases were sporadic abortion. Corbellini et al. (2006) investigated 161 bovine abortions from 149 farms bovine abortions during 2001 and 2003 from RS. Causes of abortion were identified in $83(51.5 \%)$ cases. $N$. caninum was the most important cause, and identified in 37 fetuses; in 34 fetuses, the diagnosis was confirmed by IHC examination. Overall, 37 of 161 (23\%) fetuses were infected solely with $N$. caninum. In six cases, there was concurrent Leptospira sp. infection. Most aborted fetuses were 4.4 months gestational age. Cows aborting a Neospora infected fetuses were 2.4 times likely to have aborted previously.

In a follow up publication, more detailed investigation involved 258 aborted fetuses from RS and SC. Lesions indicative of neosporosis were found in 89 (34\%) of these 258 submissions based on histopathology. The diagnosis was confirmed by IHC in 55 of these 89 cases (PESCADOR et al., 2007). A striking feature was the distribution of lesions; myositis in $92 \%$, myocarditis in $76 \%$ and pneumonitis and encephalitis in 75\%. Two of these fetuses had grossly visible pale white foci in lungs, indicative of necrosis. Overall, N. caninum was the predominant (21.3\% of 258) cause of abortion in this investigation. A similar conclusion was reached by Cabral et al. (2009), who combined histopathology, IHC, and PCR to diagnose $N$. caninum in $24.8 \%$ of 105 fetal samples from the state of SP. They detected $N$. caninum DNA in the brains of $22 \%$ (16 of 72 ), placenta of $20.0 \%$ ( 4 of 20 ), heart and liver of $16.3 \%$ (8 of 49$)$ and pool of kidney, lungs, and spleen of $10.9 \%$ (7 of 64$)$.

Additional provisional evidence for neosporosis was based on higher seropositivity in aborting versus non-aborting cows on a given farm (Table 15). However, most of these reports were provisional and not a case controlled study. In PR, samples from a herd collected over a nine-yr follow-up period were analyzed for Neospora infections (LOCATELLI-DITTRICH et al., 2001). They found that the proportion of abortions was $20 \%$ and $8 \%$, respectively for the seropositive and seronegative animals.

As mentioned in Table 1, Locatelli-Dittrich et al. (2003, 2004) isolated viable $N$. caninum from a seven-month gestational age fetus and a three-month old blind calf. However, the etiology was not confirmed because histological examination was not performed.

Goats: Fatal neosporosis has been reported from MG and RS (Table 16). Hydrocephalus was detected in a day old goat kid, which had a high titer of antibodies on IFAT (1:400) for

Table 14. Reports of $N$. caninum-associated abortion in cattle from Brazil.

\begin{tabular}{|c|c|c|c|c|c|c|}
\hline \multirow{2}{*}{ State } & \multirow{2}{*}{ No. aborted } & \multirow{2}{*}{ No. positive (\%) } & \multicolumn{3}{|c|}{ Diagnosis } & \multirow{2}{*}{ Reference } \\
\hline & & & Histo & IHC & PCR & \\
\hline Bahia & 1 & 1 & Yes & Yes & ND & Gondim et al. (1999b) \\
\hline Goiás & 195 dead fetuses from abattoir & $409(20.5)$ & No & No & Yes & Brom et al. (2014) \\
\hline Paraná & 34 & $8(23.5)$ & Yes & Yes & ND & Santos et al. (2005) \\
\hline Rio Grande do Sul & 30 & $1(3.3)$ & Yes & Yes & ND & Corbellini et al. (2000) \\
\hline Rio Grande do Sul & 46 & $22(47.8)$ & Yes & Yes & ND & Corbellini et al.(2002) \\
\hline Rio Grande do Sul & 161 & $37(17.4)$ & Yes & Yes & ND & Corbellini et al. (2006) \\
\hline Rio Grande do Sul, Santa Catarina & 258 & $55(21.3)$ & Yes & Yes & ND & Pescador et al. (2007) \\
\hline Sáo Paulo & 105 & $26(24.7)$ & Yes & Yes & Yes & Cabral et al. (2009) \\
\hline
\end{tabular}


Table 15. Seropositivity as evidence of abortion in cattle from Brazil.

\begin{tabular}{|c|c|c|c|c|c|c|c|}
\hline \multirow[b]{2}{*}{$\begin{array}{l}\text { Total number of cattle/ } \\
\text { farms examined }\end{array}$} & \multicolumn{3}{|c|}{ Aborting } & \multicolumn{3}{|c|}{ Non aborting or control } & \multirow[b]{2}{*}{ Reference } \\
\hline & Test cut-off & $\begin{array}{l}\text { No. } \\
\text { tested }\end{array}$ & $\begin{array}{l}\text { No. } \\
\text { seropositive (\%) }\end{array}$ & $\begin{array}{l}\text { No. } \\
\text { tested }\end{array}$ & $\begin{array}{c}\text { No. } \\
\text { seropositive } \\
(\%) \\
\end{array}$ & $\begin{array}{l}\text { Risk of abortion indicated by } \\
\text { odd ratio }(\mathrm{OR}) \text {, significant } \\
\text { association (SA), remarks }\end{array}$ & \\
\hline 223 dairy cows, 5 herds & IFAT, $1: 200$ & NS & NS (23.3) & NS & NS (8.3) & OR 3.3 & $\begin{array}{c}\text { Corbellini et al. } \\
\text { (2002) }\end{array}$ \\
\hline $\begin{array}{l}2448 \text { cattle from } 205 \\
\text { herds, beef, dairy }\end{array}$ & IFAT, $1: 50$ & - & $\begin{array}{l}\text { 55/68 herds } \\
(80.9)\end{array}$ & - & $\begin{array}{c}\text { 84/134 herds } \\
(62.7)\end{array}$ & OR 2.5 & $\begin{array}{l}\text { Oshiro et al. } \\
\text { (2007) }\end{array}$ \\
\hline 1256,41 aborted & IFAT, $1: 200$ & 41 & $24(58.5)$ & 1215 & $199(16.4)$ & OR 7.2 & $\begin{array}{l}\text { Hein et al. } \\
\text { (2012) }\end{array}$ \\
\hline $\begin{array}{l}1204 \text { dairy cows from } 40 \\
\text { farms }\end{array}$ & IFAT, $1: 200$ & NS & NS (31.1) & NS & NS (17.7) & OR 1.98 & $\begin{array}{l}\text { Bruhn et al. } \\
\quad(2013)\end{array}$ \\
\hline $\begin{array}{l}621 \text { cattle, } 63 \text { farms, } 36 \\
\text { farms with abortion }\end{array}$ & IFAT, $1: 100$ & - & $\begin{array}{l}26 / 36 \text { farms } \\
(72.2)\end{array}$ & - & $\begin{array}{c}12 / 27 \text { farms } \\
(44.4)\end{array}$ & SA & $\begin{array}{l}\text { Boas et al. } \\
(2015)\end{array}$ \\
\hline $\begin{array}{l}3428 \text { cattle from } 174 \\
\text { herds }\end{array}$ & IFAT, $1: 100$ & - & $\begin{array}{l}\text { 99/108 herds } \\
\text { (91.7) }\end{array}$ & - & $\begin{array}{l}\text { 11/52 herds } \\
\text { (21.1) }\end{array}$ & SA & $\begin{array}{c}\text { Chiebao et al. } \\
\text { (2015) }\end{array}$ \\
\hline $\begin{array}{l}1273 \text { cattle from } 6 \text { dairy } \\
\text { herds }\end{array}$ & IFAT, $1: 200$ & 305 & $122(40.0)$ & 968 & $40(4.1)$ & SA & $\begin{array}{l}\text { Pessoa et al. } \\
\text { (2016) }\end{array}$ \\
\hline
\end{tabular}

Table 16. Fatal neosporosis in goats from Brazil.

\begin{tabular}{|c|c|c|c|c|c|c|c|}
\hline \multirow{2}{*}{ State } & \multirow{2}{*}{ Case no. } & \multirow{2}{*}{ History } & \multicolumn{4}{|c|}{ Diagnosis } & \multirow{2}{*}{ Reference } \\
\hline & & & Serology & Histology & Immuno & PCR & \\
\hline \multirow{4}{*}{$\begin{array}{l}\text { Minas } \\
\text { Gerais }\end{array}$} & 1- day old & $\begin{array}{l}\text { Born weak, unable to } \\
\text { nurse }\end{array}$ & $\begin{array}{l}\text { Doe, IFAT } \\
1: 400\end{array}$ & $\begin{array}{l}\text { White matter absent, mild } \\
\text { necrosis, perivasculitis, only } \\
\text { tissue cysts } 9.8-20.5 \mu \mathrm{m} \text { in } \\
\text { diameter. }\end{array}$ & Positive & Not done & \multirow{2}{*}{$\begin{array}{l}\text { Varaschin et al. } \\
\text { (2012) }\end{array}$} \\
\hline & Day of birth & New born kid, late term & $\begin{array}{l}\text { IFAT doe } \\
1: 800, \\
\text { presuckling } \\
\text { kid } 1: 400\end{array}$ & No lesions in placenta & Negative & $\begin{array}{l}\text { Positive in } \\
\text { placenta. }\end{array}$ & \\
\hline & Abortion & $\begin{array}{l}\text { A chronically infected } \\
\text { aborted } 4 \text { fetuses, } 87 \text { days } \\
\text { after mating. }\end{array}$ & $\begin{array}{c}\text { IFAT doe } \\
1: 6,400 \text { at } \\
\text { abortion day. }\end{array}$ & Positive in 1. & $\begin{array}{l}\text { Brain } \\
\text { positive in } \\
1 \text { fetus }\end{array}$ & $\begin{array}{l}\text { PCR positive } \\
\text { brain in the first } \\
\text { and heart in the } \\
\text { second fetus }\end{array}$ & \multirow{2}{*}{$\begin{array}{c}\text { Mesquita et al. } \\
\text { (2013) }\end{array}$} \\
\hline & 2 stillborn & $\begin{array}{l}\text { Stillborn on } 148 \text { days } \\
\text { after mating of a } \\
\text { chronically infected doe }\end{array}$ & $\begin{array}{l}\text { IFAT doe } \\
1: 3,200 \text { at } \\
\text { parturition. }\end{array}$ & Positive in 2 . & $\begin{array}{l}\text { Positive in } \\
\text { both. }\end{array}$ & $\begin{array}{c}\text { Positive in CNS } \\
\text { of both. }\end{array}$ & \\
\hline $\begin{array}{l}\text { Rio } \\
\text { Grande } \\
\text { do Sul }\end{array}$ & 1- day old & $\begin{array}{l}\text { Born weak, unable to } \\
\text { nurse, ataxic, euthanized } \\
\text { day } 3\end{array}$ & No data & $\begin{array}{l}\text { Encephalitis, more severe } \\
\text { in mid brain, many intact } \\
\text { and degenerating tissue } \\
\text { cysts of } 12.4-32.2 \mu \mathrm{m} \text { in } \\
\text { diameter. }\end{array}$ & Positive & Not done & $\begin{array}{l}\text { Corbellini et al. } \\
\text { (2001) }\end{array}$ \\
\hline
\end{tabular}

$N$. caninum and no antibodies for $T$. gondii (VARASCHIN et al., 2012). The cerebral hemispheres of the animal were asymmetrical the gyri were swollen, and ventricles were expanded. Histologically, there were only tissue cysts in the brain, no tachyzoites were observed and no lesions were observed in histological examination of placenta. Corbellini et al. (2001) described another case in southern Brazil, with a kid presenting neurological signs as ataxia and opistothonos, which got more severe when it was three days old, and was euthanized. Brain, heart, lungs and liver had microscopic lesions, but no grossly lesions were not observed.

Humans: Currently, there is no evidence of the zoonotic character of $N$. caninum, although antibodies in humans were found in immune compromised and normal patients in different parts of the world (DUBEY et al., 2017).

In Brazil, three studies were conducted. In MG, serum samples from HIV-infected patients (Group I), patients with neurological disorders (Group II), newborns (Group III) and a healthy control (Group IV) by IFAT (1:50) were assayed for $N$. caninum antibodies by indirect ELISA to detect immunoglobulin $\mathrm{G}(\mathrm{IgG})$, utilizing soluble antigen and IB as a confirmatory test, with lysed tachyzoites as antigen (LOBATO et al., 2006). They found IB positive patients in all groups, and HIV-infected patients and those with neurological disorders patients presented significantly higher prevalence. Combining all the tests, 37.7\% (23/61) of group I, 
$18 \%(9 / 50)$ of group II, and 5\% (5/91) from groups III had antibodies to $N$. caninum.

In the second study, antibodies to $N$. caninum (IFAT,1:50) were sought in Human Immunodeficiency Virus (HIV) patients; which $26.1 \%(81 / 310)$ patients from MS and 31.2\% (10/31) patients from PR were seropositive and one patient had a titer of 1:400 (OSHIRO et al., 2015). In the third report, $N$. caninum antibodies (IFAT 1:100) were detected in 7 of 67 (10,5\%) humans from 24 farms of MT (BENETTI et al., 2009).

\section{Prospective and areas of future research}

It is evident from this review that $N$. caninum infection is widely prevalent throughout Brazil. However, nothing is known of the prevalence of $N$. caninum oocysts in soil or in canine feces. It is also uncertain if there are additional definitive hosts, other than the domestic dog and some wild canids, as stated before. Overall, little is known of clinical neosporosis, particularly in cattle. The few reports pertain to sporadic cases of abortion with no information on epidemics or storms of abortion. There is need for a national survey in cattle using defined parameters. Future researches should focus on molecular characterization of $N$. caninum strains, possibility of vaccine production and relationship between wildlife and livestock epidemiology.

\section{References}

Abreu JAP, Krawczak FS, Nunes FP, Labruna MB, Pena HFJ. AntiToxoplasma gondii and anti-Neospora caninum antibodies in capybaras (Hydrochoerus hydrochaeris) from Itu Municipality, São Paulo. Rev Bras Parasitol Vet 2016; 25(1): 116-118. PMid:26982562. http://dx.doi. org/10.1590/S1984-29612016002.

Abreu RA, Weiss RR, Thomaz-Soccol V, Locatelli-Dittrich R, Laskoski LM, Bertol MAF, et al. Association of antibodies against Neospora caninum in mares with reproductive problems and presence of seropositive dogs as a risk factor. Vet Parasitol 2014; 202(3-4): 128-131. PMid:24731383. http://dx.doi.org/10.1016/j.vetpar.2014.03.022.

Acosta ICL, Centoducatte LD, Soares HS, Marcili A, Gondim MFN, Rossi JL, et al. Occurrence of Neospora caninum and Toxoplasma gondii antibodies in dogs from rural properties surrounding a biological reserve, Espirito Santo, Brazil. Rev Bras Parasitol Vet 2016; 25(4): 536-539. PMid:27925068. http://dx.doi.org/10.1590/s1984-29612016075.

Aguiar DM, Cavalcante GT, Rodrigues AAR, Labruna MB, Camargo LMA, Camargo EP, et al. Prevalence of anti-Neospora caninum antibodies in cattle and dogs from Western Amazon, Brazil, in association with some possible risk factors. Vet Parasitol 2006; 142(1-2): 71-77. PMid:16857319. http://dx.doi.org/10.1016/j.vetpar.2006.06.014.

Aguiar DM, Chiebao DP, Rodrigues AAR, Cavalcante GT, Labruna MB, Gennari SM. Prevalência de anticorpos anti-Neospora caninum em ovinos do município de Monte Negro, RO, Amazônia Ocidental Brasileira. Arq Inst Biol 2004; 71: 616-618.

Al-Qassab S, Reichel MP, Ellis J. A second generation multiplex PCR for typing strains of Neospora caninum using six DNA targets. Mol Cell Probes 2010; 24(1): 20-26. PMid:19683051. http://dx.doi.org/10.1016/j. mcp.2009.08.002.
Al-Qassab S, Reichel MP, Ivens A, Ellis JT. Genetic diversity amongst isolates of Neospora caninum, and the development of a multiplex assay for the detection of distinct strains. Mol Cell Probes 2009; 23(3-4): 132139. PMid:19496247. http://dx.doi.org/10.1016/j.mcp.2009.01.006.

Alves AF No, Bandini LA, Nishi SM, Soares RM, Driemeier D, Antoniassi $\mathrm{NAB}$, et al. Viability of sporulated oocysts of Neospora caninum after exposure to different physical and chemical treatments. J Parasitol 2011; 97(1): 135-139. PMid:21348620. http://dx.doi.org/10.1645/GE-2571.1.

Andrade GS, Bruhn FRP, Rocha CMBM, Guimarães AS, Gouveia AMG, Guimarães AM. Seroprevalence and risk factors for Neospora caninum in sheep in the state Minas Gerais, southeastern Brazil. Vet Parasitol 2012; 188(1-2): 168-171. PMid:22475416. http://dx.doi.org/10.1016/j. vetpar.2012.03.006.

Andrade GS, Bruhn FRP, Rocha CMBM, Guimarães AS, Gouveia AMG, Guimarães AM. Seroprevalence for Neospora caninum in goats of Minas Gerais state, Brazil. Res Vet Sci 2013; 94(3): 584-586. PMid:23200513. http://dx.doi.org/10.1016/j.rvsc.2012.09.026.

André MR, Adania CH, Teixeira RHF, Silva KF, Jusi MMG, Machado STZ, et al. Antibodies to Toxoplasma gondii and Neospora caninum in captive neotropical and exotic wild canids and felids. J Parasitol 2010; 96(5): 1007-1009. PMid:20950109. http://dx.doi.org/10.1645/GE-2502.1.

Andreotti R, Barros JC, Pereira AR, Oshiro LM, Cunha RC, Figueiredo LF No. Association between seropositivity for Neospora caninum and reproductive performance of beef heifers in the Pantanal of Mato Grosso do Sul, Brazil. Rev Bras Parasitol Vet 2010; 19(2): 119-123. PMid:20624350. http://dx.doi.org/10.1590/S1984-29612010000200010.

Andreotti R, Matos MFC, Gonçalves KN, Oshiro LM, Lima-Junior MSC, Paiva F, et al. Comparison of indirect ELISA based on recombinant protein NcSRS2 and IFAT for detection of Neospora caninum antibodies in sheep. Rev Bras Parasitol Vet 2009; 18(2): 19-22. PMid:19602311. http://dx.doi.org/10.4322/rbpv.01802004.

Andreotti R, Oliveira JM, Silva EA, Oshiro LM, Matos MFC. Occurrence of Neospora caninum in dogs and its correlation with visceral leishmaniasis in the urban area of Campo Grande, Mato Grosso do Sul, Brazil. Vet Parasitol 2006; 135(3-4): 375-379. PMid:16310954. http://dx.doi. org/10.1016/j.vetpar.2005.10.011.

Andreotti R, Pinckney RD, Pires PP, Silva EAE. Evidence of Neospora caninum in beef cattle and dogs in the state of Mato Grosso do Sul, center-western region, Brazil. Rev Bras Parasitol Vet 2004; 13(3): 129-131.

Antonello AM, Pivoto FL, Camillo G, Braunig P, Sangioni LA, Pompermayer E, et al. The importance of vertical transmission of Neospora sp. in naturally infected horses. Vet Parasitol 2012; 187(3-4): 367-370. PMid:22436425. http://dx.doi.org/10.1016/j.vetpar.2012.02.005.

Arraes-Santos AI, Araújo AC, Guimarães MF, Santos JR, Pena HFJ, Gennari SM, et al. Seroprevalence of anti-Toxoplasma gondii and antiNeospora caninum antibodies in domestic mammals from two distinct regions in the semi-arid region of Northeastern Brazil. Vet Parasit: Reg Stud Rep 2016; 5: 14-18.

Azevedo SS, Batista CSA, Vasconcellos SA, Aguiar DM, Ragozo AMA, Rodrigues AAR, et al. Seroepidemiology of Toxoplasma gondii and Neospora caninum in dogs from the state of Paraíba, Northeast region of Brazil. Res Vet Sci 2005; 79(1): 51-56. PMid:15894024. http://dx.doi. org/10.1016/j.rvsc.2004.10.001.

Azevedo SS, Pena HFJ, Alves CJ, Guimarães AAM, Oliveira RM, Maksimov P, et al. Prevalence of anti-Toxoplasma gondii and anti-Neospora caninum antibodies in swine from Northeastern Brazil. Rev Bras Parasitol 
Vet 2010; 19(2): 80-84. PMid:20624342. http://dx.doi.org/10.1590/ S1984-29612010000200002.

Balthazar LMC, Leal PDS, Teixeira Filho WL, Lopes CWG. Cães sororreagentes a Neospora caninum (Apicomplexa: Toxoplasmatinae) atendidos em uma clínica veterinária na cidade do Rio de Janeiro, RJ. Rev Bras Med Vet 2013; 35(S2): 48-51.

Bandini LA, Neto AFA, Pena HFJ, Cavalcante GT, Schares G, Nishi SM, et al. Experimental infection of dogs (Canis familiaris) with sporulated oocysts of Neospora caninum. Vet Parasitol 2011; 176(2-3): 151-156. PMid:21094584. http://dx.doi.org/10.1016/j.vetpar.2010.10.047.

Benetti AH, Schein FB, Santos TR, Toniollo GH, Costa AJ, Mineo $\mathrm{JR}$, et al. Pesquisa de anticorpos anti-Neospora caninum em bovinos leiteiros, cães e trabalhadores rurais da região Sudoeste do Estado de Mato Grosso. Rev Bras Parasitol Vet 2009;18(Suppl 1): 29-33. PMid:20040187. http://dx.doi.org/10.4322/rbpv.018e1005.

Benetti AH, Toniollo GH, Santos TR, Gennari SM, Costa AJ, Dias RA. Ocorrência de anticorpos anti-Neospora caninum em cães no município de Cuiabá, Mato Grosso. Ciênc Anim Bras 2008; 9(1): 177-180.

Bezerra MA, Pereira LM, Bononi A, Biella CA, Baroni L, Pollo-Oliveira L, et al. Constitutive expression and characterization of a surface SRS (NcSRS67) protein of Neospora caninum with no orthologue in Toxoplasma gondii. Parasitol Int 2017; 66(2): 173-180. PMid:28108401. http:// dx.doi.org/10.1016/j.parint.2017.01.010.

Boas RV, Pacheco TA, Melo ALT, Oliveira ACS, Aguiar DM, Pacheco RC. Infection by Neospora caninum in dairy cattle belonging to family farmers in the northern region of Brazil. Rev Bras Parasitol Vet 2015; 24(2): 204208. PMid:26154960. http://dx.doi.org/10.1590/S1984-29612015035.

Boaventura CM, Oliveira VSF, Melo DPG, Borges LMF, Silva AC. Prevalência de Neospora caninum em cães de Goiânia. Rev Patol Trop 2008; 37(1): 15-22. http://dx.doi.org/10.5216/rpt.v37i1.4027.

Braga MSCO, Andre MR, Jusi MMG, Freschi CR, Teixeira MCA, Machado RZ. Occurrence of anti-Toxoplasma gondii and anti-Neospora caninum antibodies in cats with outdoor access in São Luís, Maranhão, Brazil. Rev Bras Parasitol Vet 2012; 21(2): 107-111. PMid:22832749. http://dx.doi.org/10.1590/S1984-29612012000200007.

Brasil AWL, Parentoni RN, Feitosa TF, Bezerra CS, Vilela VLR, Pena HFJ, et al. Risk factors for Toxoplasma gondii and Neospora caninum seropositivity in buffaloes in Paraíba State, Brazil. Rev Bras Parasitol Vet 2015; 24(4): 459-463. PMid:26689181. http://dx.doi.org/10.1590/ S1984-29612015066.

Bresciani KDS, Costa AJ, Nunes CM, Serrano ACM, Moura AB, Stobbe NS, et al. Ocorrência de anticorpos contra Neospora caninum e Toxoplasma gondii e estudo de fatores de risco em cães de Araçatuba - SP. Ars Vet 2007b; 23: 40-46.

Bresciani KDS, Gennari SM, Serrano ACM, Rodrigues AAR, Ueno T, Franco LG, et al. Antibodies to Neospora caninum and Toxoplasma gondii in domestic cats from Brazil. Parasitol Res 2007a; 100(2): 281 285. PMid:16941188. http://dx.doi.org/10.1007/s00436-006-0262-4.

Brom PRF, Regidor-Cerrillo J, Collantes-Fernández E, Ortega-Mora LM, Guimarães MS, Silva AC. Genetic characterisation of Neospora caninum strains from clinical samples of zebuine foetuses obtained in abattoirs in Goiás, Brazil. Vet Parasitol 2014; 204(3-4): 381-387. PMid:24893690. http://dx.doi.org/10.1016/j.vetpar.2014.05.011.

Bruhn FRP, Daher DO, Lopes E, Barbieri JM, Rocha CMBM, Guimarães AM. Factors associated with seroprevalence of Neospora caninum in dairy cattle in southeastern Brazil. Trop Anim Health Prod 2013; 45(5): $1093-$ 1098. PMid:23212838. http://dx.doi.org/10.1007/s11250-012-0330-y.

Bruhn FRP, Figueiredo VC, Andrade GS, Costa-Júnior LM, Rocha CMBM, Guimarães AM. Occurrence of anti-Neospora caninum antibodies in dogs in rural areas in Minas Gerais, Brazil. Rev Bras Parasitol Vet 2012; 21(2): 161-164. PMid:22832759. http://dx.doi.org/10.1590/S198429612012000200017

Cabral AD, Camargo CN, Galleti NTC, Okuda LH, Pituco EM, Del Fava C. Diagnosis of Neospora caninum in bovine fetuses by histology, immunohistochemistry, and nested-PCR. Rev Bras Parasitol Vet 2009 18(4): 14-19. PMid:20040203. http://dx.doi.org/10.4322/rbpv.01804003.

Cañón-Franco WA, Bergamaschi DP, Labruna MB, Camargo LMA, Souza SLP, Silva JCR, et al. Prevalence of antibodies to Neospora caninum in dogs from Amazon, Brazil. Vet Parasitol 2003; 115(1): 71-74. PMid:12860070. http://dx.doi.org/10.1016/S0304-4017(03)00131-6.

Cañón-Franco WA, Yai LEO, Souza SLP, Santos LC, Farias NAR, Ruas $\mathrm{J}$, et al. Detection of antibodies to Neospora caninum in two species of wild canids, Lycalopex gymnocercus and Cerdocyon thous from Brazil. Vet Parasitol 2004; 123(3-4): 275-277. PMid:15325054. http://dx.doi. org/10.1016/j.vetpar.2004.06.004.

Cardoso JMS, Amaku M, Araújo AJUS, Gennari SM. A longitudinal study of Neospora caninum infection on three dairy farms in Brazil. Vet Parasitol 2012a; 187(3-4): 553-557. PMid:22309800. http://dx.doi. org/10.1016/j.vetpar.2012.01.019.

Cardoso JMS, Amaku M, Araújo AJUS, Gennari SM. Neospora caninum: analysis of reproductive parameters in dairy herds in Brazil. Braz JVet Res Anim Sci 2012b; 49(6): 459-464. http://dx.doi.org/10.11606/issn.16784456.v49i6p459-464.

Cardoso JMS, Nishi SM, Funada MR, Amaku M, Guimarães JS Jr, Gennari SM. Antibody dynamics during gestation in cows naturally infected with Neospora caninum from four dairy herds in Brazil. Braz J Vet Res Anim Sci 2009; 46(5): 395-399. http://dx.doi.org/10.11606/ issn.1678-4456.bjvras.2009.26789.

Cavalcante GT, Monteiro RM, Soares RM, Nishi SM, Alves Neto AF, Esmerini PO, et al. Shedding of Neospora caninum oocysts by dogs fed different tissues from naturally infected cattle. Vet Parasitol 2011; 179(1-3): 220-223. PMid:21450407. http://dx.doi.org/10.1016/j. vetpar.2011.02.026.

Cavalcante GT, Soares RM, Nishi SM, Hagen SCF, Vannucchi CI, Maiorka PC, et al. Experimental infection with Neospora caninum in pregnant bitches. Rev Bras Parasitol Vet 2012; 21(3): 232-236. PMid:23070432. http://dx.doi.org/10.1590/S1984-29612012000300010.

Chahan B, Gaturaga I, Huang X, Liao M, Fukumoto S, Hirata H, et al. Serodiagnosis of Neospora caninum infection in cattle by enzyme-linked immunosorbent assay with recombinant truncated NcSAG1. Vet Parasitol 2003; 118(3-4): 177-185. PMid:14729165. http://dx.doi.org/10.1016/j. vetpar.2003.10.010.

Chiebao DP, Valadas SYOB, Minervino AHH, Castro V, Romaldini AHCN, Calhau AS, et al. Variables associated with infections of cattle by Brucella abortus, Leptospira spp. and Neospora spp. in Amazon Region in Brazil. Transbound Emerg Dis 2015; 62(5): e30-e36. PMid:26302373. http://dx.doi.org/10.1111/tbed.12201.

Chryssafidis AL, Cantón G, Chianini F, Innes EA, Madureira EH, Gennari SM. Pathogenicity of Nc-Bahia and Nc-1 strains of Neospora caninum in experimentally infected cows and buffaloes in early pregnancy. Parasitol Res 2014; 113(4): 1521-1528. PMid:24562816. http://dx.doi. org/10.1007/s00436-014-3796-x. 
Chryssafidis AL, Cantón G, Chianini F, Innes EA, Madureira EH, Soares RM, et al. Abortion and foetal lesions induced by Neospora caninum in experimentally infected water buffalos (Bubalus bubalis). Parasitol Res 2015; 114(1): 193-199. PMid:25324135. http://dx.doi.org/10.1007/ s00436-014-4178-0.

Chryssafidis AL, Soares RM, Rodrigues AAR, Carvalho NAT, Gennari SM. Evidence of congenital transmission of Neospora caninum in naturally infected water buffalo (Bubalus bubalis) fetus from Brazil. Parasitol Res 2011; 108(3): 741-743. PMid:21181191. http://dx.doi.org/10.1007/ s00436-010-2214-2.

Coelho WMD, Amarante AFT, Apolinário JC, Coelho NMD, Lima VMF, Perri SHV, et al. Seroepidemiology of Toxoplasma gondii, Neospora caninum, and Leishmania spp. infections and risk factors for cats from Brazil. Parasitol Res 2011; 109(4): 1009-1013. PMid:21626423. http:// dx.doi.org/10.1007/s00436-011-2461-x.

Constantino C, Pellizzaro M, Paula EFE, Vieira TSWJ, Brandão APD, Ferreira F, et al. Serosurvey for Leishmania spp., Toxoplasma gondii, Trypanosoma cruzi and Neospora caninum in neighborhood dogs in Curitiba-Paraná, Brazil. Rev Bras Parasitol Vet 2016; 25(4): 504-510. PMid:27925057. http://dx.doi.org/10.1590/s1984-29612016062.

Corbellini LG, Colodel EM, Driemeier D. Granulomatous encephalitis in a neurologically impaired goat kid associated with degeneration of Neospora caninum tissue cysts. J Vet Diagn Invest 2001; 13(5): 416-419. PMid:11580064. http://dx.doi.org/10.1177/104063870101300509.

Corbellini LG, Driemeier D, Cruz C, Dias MM. Aborto bovino por Neospora caninum no Rio Grande do Sul. Cienc Rural 2000; 30(5): 863868. http://dx.doi.org/10.1590/S0103-84782000000500021.

Corbellini LG, Driemeier D, Cruz CFE, Gondim LFP, Wald V. Neosporosis as a cause of abortion in dairy cattle in Rio Grande do Sul, southern Brazil. Vet Parasitol 2002; 103(3): 195-202. PMid:11750112. http:// dx.doi.org/10.1016/S0304-4017(01)00600-8.

Corbellini LG, Smith DR, Pescador CA, Schmitz M, Correa A, Steffen DJ, et al. Herd-level risk factors for Neospora caninum seroprevalence in dairy farms in southern Brazil. Prev Vet Med 2006; 74(2-3): 130-141. PMid:16343669. http://dx.doi.org/10.1016/j.prevetmed.2005.11.004.

Costa GHN, Cabral DD, Varandas NP, Sobral EA, Borges FA, Castagnolli KC. Freqüência de anticorpos anti-Neospora caninum e anti-Toxoplasma gondii em soros de bovinos pertencentes aos estados de São Paulo e de Minas Gerais. Semina Cienc Agrar 2001; 22(1): 61-66. http://dx.doi. org/10.5433/1679-0359.2001v22n1p61.

Costa HF, Stachissini AVM, Langoni H, Padovani CR, Gennari SM, Modolo JR. Reproductive failures associated with antibodies against caprine arthritis-encephalitis virus, Toxoplasma gondii and Neospora caninum in goats in the state of São Paulo, Brazil. Braz J Vet Res Anim Sci 2012; 49(1): 67-72. http://dx.doi.org/10.11606/issn.2318-3659.v49i1p67-72.

Costa KS, Santos SL, Uzêda RS, Pinheiro AM, Almeida MAO, Araújo FR, et al. Chickens (Gallus domesticus) are natural intermediate hosts of Neospora caninum. Int J Parasitol 2008; 38(2): 157-159. PMid:18054356. http://dx.doi.org/10.1016/j.ijpara.2007.10.008.

Cringoli G, Rinaldi L, Capuano F, Baldi L, Veneziano V, Capelli G. Serological survey of Neospora caninum and Leishmania infantum coinfection in dogs. Vet Parasitol 2002; 106(4): 307-313. PMid:12079736. http://dx.doi.org/10.1016/S0304-4017(02)00114-0.

Cunha NA Fo, Lucas AS, Pappen FG, Ragozo AMA, Gennari SM, Lucia $\mathrm{Jr} \mathrm{T}$, et al. Fatores de risco e prevalência de anticorpos anti-Neospora caninum em cães urbanos e rurais do Rio Grande do Sul, Brasil. Rev Bras Parasitol Vet 2008;17(Suppl 1): 301-306. PMid:20059865.
Dubey JP, Hemphill A, Calero-Bernal R, Schares G. Neosporosis in animals. Boca Raton: CRC Press; 2017.

Dubey JP, Kerber CE, Granstrom DE. Serologic prevalence of Sarcocystis neurona, Toxoplasma gondii, and Neospora caninum in horses in Brazil. J Am Vet Med Assoc 1999; 215(7): 970-972. PMid:10511862.

Dubey JP, Lindsay DS, Hill D, Romand S, Thulliez P, Kwok OCH, et al. Prevalence of antibodies to Neospora caninum and Sarcocystis neurona in sera of domestic cats from Brazil. J Parasitol 2002; 88(6): 1251-1252. PMid:12537122. http://dx.doi.org/10.1645/0022-3395(2002)088[1251:PO ATNC]2.0.CO;2.

Faria EB, Cavalcanti EF, Medeiros ES, Pinheiro JW Jr, Azevedo SS, Athayde AC, et al. Risk factors associated with Neospora caninum seropositivity in sheep from the State of Alagoas, in the northeast region of Brazil. J Parasitol 2010; 96(1): 197-199. PMid:19799489. http:// dx.doi.org/10.1645/GE-2176.1.

Faria EB, Gennari SM, Pena HFJ, Athayde ACR, Silva MLCR, Azevedo SS. Prevalence of anti-Toxoplasma gondii and anti-Neospora caninum antibodies in goats slaughtered in the public slaughterhouse of Patos city, Paraíba State, Northeast region of Brazil. Vet Parasitol 2007; 149(1-2): 126129. PMid:17706359. http://dx.doi.org/10.1016/j.vetpar.2007.07.009.

Fávero JF, Silva AS, Campigotto G, Machado G, Barros LD, Garcia JL, et al. Risk factors for Neospora caninum infection in dairy cattle and their possible cause-effect relation for disease. Microb Pathog 2017; 110: 202207. PMid:28666842. http://dx.doi.org/10.1016/j.micpath.2017.06.042.

Fehlberg HF, Maciel BM, Albuquerque GR. Identification and discrimination of Toxoplasma gondii, Sarcocystis spp., Neospora spp., and Cryptosporidium spp. by righ-resolution melting analysis. PLoS One 2017; 12(3): e0174168. PMid:28346485. http://dx.doi.org/10.1371/ journal.pone.0174168.

Feitosa TF, Vilela VLR, Dantas ES, Souto DVO, Pena HFJ, Athayde ACR, et al. Toxoplasma gondii and Neospora caninum in domestic cats from the Brazilian semi-arid: seroprevalence and risk factors. Arq Bras Med Vet Zootec 2014a; 66(4): 1060-1066. http://dx.doi.org/10.1590/1678-6696.

Feitosa TF, Vilela VLR, Melo LRB, Almeida JL No, Souto DVO, Morais DF, et al. Toxoplasma gondii and Neospora caninum in slaughtered pigs from Northeast, Brazil. Vet Parasitol 2014b; 202(3-4): 305-309. PMid:24703253. http://dx.doi.org/10.1016/j.vetpar.2014.03.015.

Fernandes BCTM, Gennari SM, Souza SLP, Carvalho JM, Oliveira WG, Cury MC. Prevalence of anti-Neospora caninum antibodies in dogs from urban, periurban and rural areas of the city of Uberlândia, Minas Gerais - Brazil. Vet Parasitol 2004; 123(1-2): 33-40. PMid:15265569. http://dx.doi.org/10.1016/j.vetpar.2004.05.016.

Ferreira MST, Vogel FSF, Sangioni LA, Weber A, Bräunig P, Vaz MAB, et al. Oral infection of neonate gerbils by Neospora caninum tachyzoites. Cienc Rural 2016; 46(4): 654-659. http://dx.doi.org/10.1590/0103$8478 \mathrm{cr} 20150475$.

Figliuolo LPC, Kasai N, Ragozo AMA, Paula VSO, Dias RA, Souza SLP, et al. Prevalence of anti-Toxoplasma gondii and anti-Neospora caninum antibodies in ovine from São Paulo State, Brazil. Vet Parasitol 2004a; 123(3-4): 161-166. PMid:15325042. http://dx.doi.org/10.1016/j. vetpar.2004.06.006.

Figliuolo LPC, Rodrigues AAR, Viana RB, Aguiar DM, Kasai N, Gennari SM. Prevalence of anti-Toxoplasma gondii and anti-Neospora caninum antibodies in goat from São Paulo State, Brazil. Small Rumin Res 2004b; 55(1-3): 29-32. http://dx.doi.org/10.1016/j.smallrumres.2003.12.013. 
Figueredo LA, Dantas-Torres F, de Faria EB, Gondim LFP, SimóesMattos L, Brandão-Filho SP, et al. Occurrence of antibodies to Neospora caninum and Toxoplasma gondii in dogs from Pernambuco, Northeast Brazil. Vet Parasitol2008; 157(1-2): 9-13. PMid:18723288. http://dx.doi. org/10.1016/j.vetpar.2008.07.009.

Filho PCGA, Oliveira JMB, Andrade MR, Silva JG, Kim PCP, Almeida JC, et al. Incidence and vertical transmission rate of Neospora caninum in sheep. Comp Immunol Microbiol Infect Dis 2017; 52: 19-22. PMid:28673457. http://dx.doi.org/10.1016/j.cimid.2017.05.006.

Fujii TU, Kasai N, Nishi SM, Dubey JP, Gennari SM. Seroprevalence of Neospora caninum in female water buffaloes (Bubalus bubalis) from the southeastern region of Brazil. Vet Parasitol 2001a; 99(4): 331-334. PMid:11511420. http://dx.doi.org/10.1016/S0304-4017(01)00474-5.

Fujii TU, Kasai N, Vasconcellos SA, Richtzenhain LJ, Cortez A, Souza SLP, et al. Anticorpos anti-Neospora caninum e contra outros agentes de abortamentos em búfalas da região do Vale do Ribeira, São Paulo, Brasil. Arq Inst Biol (Sao Paulo) 2001b; 68(2): 5-9.

Furuta PI, Mineo TWP, Carrasco AOT, Godoy GS, Pinto AA, Machado RZ. Neospora caninum infection in birds: experimental infections in chicken and embryonated eggs. Parasitology 2007; 134(Pt14): 1931-1939. PMid:17686190. http://dx.doi.org/10.1017/S0031182007003344.

Galvão CMMQ, Rezende-Gondim MM, Chaves ACR, Schares G, Ribas JRL, Gondim LFP. Brazilian donkeys (Equus asinus) have a low exposure to Neospora spp. Rev Bras Parasitol Vet 2015; 24(3): 340-344. PMid:26444065. http://dx.doi.org/10.1590/S1984-29612015057.

García-Melo DP, Regidor-Cerrillo J, Ortega-Mora LM, Collantes-Fernández E, Oliveira VSF, Oliveira MAP, et al. Isolation and biological characterisation of a new isolate of Neospora caninum from an asymptomatic calf in Brazil. Acta Parasitol 2009; 54(2): 180-185. http://dx.doi.org/10.2478/ s11686-009-0018-2.

Gennari SM, Cañón-Franco WA, Feitosa MM, Ikeda FA, Lima VMF, Amaku M.. Presence of anti-Neospora caninum and Toxoplasma gondii antibodies in dogs with visceral leishmaniosis from the region of Araçatuba, São Paulo, Brazil. Braz J Vet Res Anim Sci 2006; 43(5): 613-619. http:// dx.doi.org/10.11606/issn.1678-4456.bjvras.2006.26569.

Gennari SM, Pena HFJ, Lindsay DS, Lopes MG, Soares HS, Cabral $\mathrm{AD}$, et al. Prevalence of antibodies against Neospora spp. and Sarcocystis neurona in donkeys from northeastern Brazil. Rev Bras Parasitol Vet 2016; 25(1): 109-111. PMid:26982557. http://dx.doi.org/10.1590/ S1984-29612016003.

Gennari SM, Rodrigues AAR, Viana RB, Cardoso EC. Occurrence of anti-Neospora caninum antibodies in water buffaloes (Bubalus bubalis) from the northern region of Brazil. Vet Parasitol 2005; 134(1-2): 169171. PMid:16051440. http://dx.doi.org/10.1016/j.vetpar.2005.05.064.

Gennari SM, Yai LEO, D’Áuria SNR, Cardoso SMS, Kwok OCH, Jenkins $\mathrm{MC}$, et al. Occurrence of Neospora caninum antibodies in sera from dogs of the city of São Paulo, Brazil. Vet Parasitol 2002; 106(2): 177-179. PMid:12031819. http://dx.doi.org/10.1016/S0304-4017(02)00052-3.

Giraldi JH, Bracarense APFRL, Vidotto O, Tudury EA, Navarro IT, Batista TN. Sorologia e histopatologia de Toxoplasma gondii e Neospora caninum em cães portadores de distúrbios neurológicos. Semina Cienc Agrar 2002; 23(1): 9-14. http://dx.doi.org/10.5433/1679-0359.2002v23n1p9.

Gonçalves IN, Uzêda RS, Lacerda GA, Moreira RRN, Araújo FR, Oliveira RHM, et al. Molecular frequency and isolation of cyst-forming coccidia from free ranging chickens in Bahia State, Brazil. Vet Parasitol 2012; 190(1-2): 74-79. PMid:22673105. http://dx.doi.org/10.1016/j. vetpar.2012.05.007.
Gondim LFP, Laski P, Gao L, McAllister MM. Variation of the internal transcribed spacer 1 sequence within individual strains and among different strains of Neospora caninum. J Parasitol 2004; 90(1): 119-122. PMid:15040677. http://dx.doi.org/10.1645/GE-134R.

Gondim LFP, Pinheiro AM, Almeida MAO. Frequência de anticorpos anti-Neospora caninum em búfalos (Bubalus bubalis) criados no estado da Bahia. Rev Bras Saúde Prod Anim 2007; 8(2): 92-96.

Gondim LFP, Pinheiro AM, Santos POM, Jesus EEV, Ribeiro MB, Fernandes HS, et al. Isolation of Neospora caninum from the brain of a naturally infected dog, and production of encysted bradyzoites in gerbils. Vet Parasitol 2001; 101(1): 1-7. PMid:11587828. http://dx.doi. org/10.1016/S0304-4017(01)00493-9.

Gondim LFP, Sartor IF, Hasegawa M, Yamane I. Seroprevalence of Neospora caninum in dairy cattle in Bahia, Brazil. Vet Parasitol 1999a; 86(1): 71-75. PMid:10489205. http://dx.doi.org/10.1016/S0304-4017(99)00129-6.

Gondim LFP, Sartor IF, Monteiro LA Jr, Haritani M. Neospora caninum infection in an aborted bovine foetus in Brazil. NZ Vet J 1999b; 47(1): 35. PMid:16032066. http://dx.doi.org/10.1080/00480169.1999.36106.

Gondim LSQ, Abe-Sandes K, Uzêda RS, Silva MSA, Santos SL, Mota RA, et al. Toxoplasma gondii and Neospora caninum in sparrows (Passer domesticus) in the Northeast of Brazil. Vet Parasitol 2010; 168(1-2): 121 124. PMid:19879051. http://dx.doi.org/10.1016/j.vetpar.2009.09.055.

Greca H, Silva AV, Langoni H. Associação entre a presença de anticorpos anti-Leishmania sp. e anti-Neospora caninum cães de Bauru, SP. Arq Bras Med Vet Zootec 2010; 62(1): 224-227. http://dx.doi.org/10.1590/ S0102-09352010000100032.

Guedes MHP, Guimarães AM, Rocha CMBM, Hirsch C. Frequência de anticorpos anti-Neospora caninum em vacas e fetos provenientes de municípios do sul de Minas Gerais. Rev Bras Parasitol Vet 2008; 17(4): 189-194. PMid:19265576. http://dx.doi.org/10.1590/S198429612008000400004 .

Guimarães AM, Rocha CMBM, Oliveira TMFS, Rosado IR, Morais LG, Santos RRD. Fatores associados à soropositividade para Babesia, Toxoplasma, Neospora e Leishmania em cães atendidos em nove clínicas veterinárias do município de Lavras, MG. Rev Bras Parasitol Vet 2009;18(Suppl 1): 49-53. PMid:20040191. http://dx.doi.org/10.4322/rbpv.018e1009.

Guimarães JS Jr, Souza SLP, Bergamaschi DP, Gennari SM. Prevalence of Neospora caninum antibodies and factors associated with their presence in dairy cattle of the north of Paraná state, Brazil. Vet Parasitol 2004; 124(1-2): 1-8. PMid:15350656. http://dx.doi.org/10.1016/j.vetpar.2004.07.002.

Hasegawa MY, Sartor IF, Canavessi AMO, Pinckney RD. Ocorrência de anticorpos anti-Neospora caninum em bovinos de corte e em cães rurais da região de Avaré, Estado de São Paulo, Brasil. Semina Cienc Agrar 2004; 25(1): 45-50.

Hein HE, Machado G, Miranda ICS, Costa EF, Pellegrini DCP, Driemeier $\mathrm{D}$, et al. Neosporose bovina: avaliação da transmissão vertical e fração atribuível de aborto em uma população de bovinos no Estado do Rio Grande do Sul. Pesq Vet Bras 2012; 32(5): 396-400. http://dx.doi. org/10.1590/S0100-736X2012000500006.

Higa AC, Machado RZ, Tinucci-Costa M, Domingues LM, Malheiros EB. Evaluation of cross-reactivity of Toxoplasma gondii and Neospora caninum antigens in dogs sera. Rev Bras Parasitol Vet 2000; 9(2): 91-95.

Hoane JS, Gennari SM, Dubey JP, Ribeiro MG, Borges AS, Yai LEO, et al. Prevalence of Sarcocystis neurona and Neospora spp. infection in horses from Brazil based on presence of serum antibodies to parasite surface 
antigen. Vet Parasitol 2006; 136(2): 155-159. PMid:16310955. http:// dx.doi.org/10.1016/j.vetpar.2005.10.023.

Hoffmann Kormann DCS, Locatelli-Dittrich R, Richartz RRTB, Antunes J, Dittrich JR, Patrício LFL. Soroprevalência e cinética mensal de anticorpos anti-Neospora sp. em éguas gestantes. Rev Bras Parasitol Vet 2008;17(Suppl 1): 335-338. PMid:20059873.

Jesus EEV, Santos POM, Barbosa MVF, Pinheiro AM, Gondim LFP, Guimarães JE, et al. Frequência de anticorpos anti-Neospora caninum em cães nos municípios de Salvador e Lauro de Freitas, Estado da Bahia - Brasil. Braz J Vet Res Anim Sci 2006; 43(1): 5-10. http://dx.doi. org/10.11606/issn.1678-4456.bjvras.2006.26511.

Klauck V, Machado G, Pazinato R, Radavelli WM, Santos DS, Berwaguer JC, et al. Relation between Neospora caninum and abortion in dairy cows: Risk factors and pathogenesis of disease. Microb Pathog 2016; 92: 46-49. PMid:26747583. http://dx.doi.org/10.1016/j.micpath.2015.12.015.

Langoni H, Fornazari F, Silva RC, Monti ET, Villa FB. Prevalence of antibodies against Toxoplasma gondii and Neospora caninum in dogs. Braz J Microbiol 2014; 44(4): 1327-1330. PMid:24688530. http://dx.doi. org/10.1590/S1517-83822013000400043.

Langoni H, Greca H Jr, Guimarães FF, Ullmann LS, Gaio FC, Uehara RS, et al. Serological profile of Toxoplasma gondii and Neospora caninum infection in commercial sheep from São Paulo State, Brazil. Vet Parasitol 2011; 177(1-2): 50-54. PMid:21256676. http://dx.doi.org/10.1016/j. vetpar.2010.11.024.

Langoni H, Matteucci G, Medici B, Camossi LG, Richini-Pereira VB, Silva RC. Detection and molecular analysis of Toxoplasma gondii and Neospora caninum from dogs with neurological disorders. Rev Soc Bras Med Trop 2012; 45(3): 365-368. PMid:22760137. http://dx.doi.org/10.1590/ S0037-86822012000300016.

Laskoski LM, Muraro LS, Dittrich RL, Abreu RA, Koch MO, Silva FT, et al. Occurrence of anti-Neospora caninum and anti-Toxoplasma gondii antibodies in horses in the Pantanal of Mato Grosso, Brazil. Semina Cienc Agrar 2015; 36(2): 895-900. http://dx.doi.org/10.5433/16790359.2015v36n2p895.

Lima JTR, Ahid SMM, Barrêto RA Jr, Pena HFJ, Dias RA, Gennari SM. Prevalência de anticorpos anti-Toxoplasma gondii e anti-Neospora caninum em rebanhos caprinos do município de Mossoró, Rio Grande do Norte. BrazJ Vet Res Anim Sci 2008; 45(2): 81-86. http://dx.doi.org/10.11606/ issn.1678-4456.bjvras.2008.26703.

Lobato J, Silva DAO, Mineo TWP, Amaral JDHF, Segundo GRS, CostaCruz JM, et al. Detection of immunoglobulin G antibodies to Neospora caninum in humans: high seropositivity rates in patients who are infected by human immunodeficiency virus or have neurological disorders. Clin Vaccine Immunol 2006; 13(1): 84-89. PMid:16426004. http://dx.doi. org/10.1128/CVI.13.1.84-89.2006.

Locatelli-Dittrich R, Dittrich JR, Richartz RRTB, Gasino-Joineau ME, Antunes J, Pinckney RD, et al. Investigation of Neospora sp. and Toxoplasma gondii antibodies in mares and in precolostral foals from Paraná State, Southern Brazil. Vet Parasitol 2006; 135(3-4): 215-221. PMid:16289863. http://dx.doi.org/10.1016/j.vetpar.2005.10.010.

Locatelli-Dittrich R, Machado PC Jr, Fridlund-Plugge N, Richartz RRTB, Montiani-Ferreira F, Patrício LFL, et al. Determinação e correlação de anticorpos anti-Neospora caninum em bovinos e cães do Paraná, Brasil. Rev Bras Parasitol Vet 2008;17(Suppl 1): 191-196. PMid:20059847.

Locatelli-Dittrich R, Soccol VT, Richartz RRTB, Gasino-Joineau ME, Vinne R, Pinckney RD. Serological diagnosis of neosporosis in a herd of dairy cattle in southern Brazil. J Parasitol 2001; 87(6): 1493-1494.
PMid:11780849. http://dx.doi.org/10.1645/0022-3395(2001)087[1493:SD ONIA]2.0.CO;2.

Locatelli-Dittrich R, Soccol VT, Richartz RRTB, Gasino-Joineau ME, van der Vinne R, Pinckney RD. Isolamento de Neospora caninum de feto bovino de rebanho leiteiro no Paraná. Rev Bras Parasitol Vet 2004; 13(3): 103-109.

Locatelli-Dittrich R, Sousa RS, Leite LC, Thomaz-Soccol V, Richartz RRTB, Joineau MEG, et al. Isolation of Neospora caninum from a blind calf in Paraná, southern Brazil. Vet Rec 2003; 153(12): 366-367. PMid:14533770. http://dx.doi.org/10.1136/vr.153.12.366.

Lopes MG, Mendonça IL, Fortes KP, Amaku M, Pena HFJ, Gennari SM. Presence of antibodies against Toxoplasma gondii, Neospora caninum and Leishmania infantum in dogs from Piauí. Rev Bras Parasitol Vet 2011; 20(2): 111-114. PMid:21722484. http://dx.doi.org/10.1590/S198429612011000200004.

Machado GP, Kikuti M, Langoni H, Paes AC. Seroprevalence and risk factors associated with neosporosis in sheep and dogs from farms. Vet Parasitol 2011; 182(2-4): 356-358. PMid:21676548. http://dx.doi. org/10.1016/j.vetpar.2011.05.021.

Mann TR, Cadore GC, Camillo G, Vogel FSF, Schmidt C, Andrade CM. Canine cutaneous neosporosis in Brazil. Vet Dermatol 2016; 27(3): 195-197. PMid:26949109. http://dx.doi.org/10.1111/vde.12294.

Marques FAC, Headley AS, Figueredo-Pereira V, Taroda A, Barros LD, Cunha IAL, et al. Neospora caninum: evaluation of vertical transmission in slaughtered beef cows (Bos indicus). Parasitol Res 2011; 108(4): 10151019. PMid:21063729. http://dx.doi.org/10.1007/s00436-010-2146-x.

Martins AA, Zamprogna TO, Lucas TM, Cunha IAL, Garcia JL, Silva $\mathrm{AV}$. Frequency and risk factors for infection by Neospora caninum in dairy farms of Umuarama, PR, Brazil. Arq Ciênc Vet Zool 2012; 15(2): 137-142.

Martins NÉX, Freschi CR, Baptista F, Machado RZ, Freitas FLC, Almeida KS. Ocorrência de anticorpos anti-Neospora caninum em vacas lactantes do município de Araguaína, estado do Tocantins, Brasil. Rev Patol Trop 2011; 40(3): 231-238.

Mello RC, Andreotti R, Barros JC, Tomich RGP, Mello AKM, Campolim AI, et al. Levantamento epidemiológico de Neospora caninum em bovinos de assentamentos rurais em Corumbá, MS. Rev Bras Parasitol Vet 2008;17(Suppl 1): 311-316. PMid:20059867.

Melo CB, Leite RC, Leite FSC, Leite RC. Serological surveillance on South American wild canids for Neospora caninum. Arq Bras Med Vet Zootec 2002; 54(4): 444-447. http://dx.doi.org/10.1590/S0102-09352002000400018.

Melo CB, Leite RC, Lobato ZIP, Leite RC. Infection by Neospora caninum associated with bovine herpesvirus 1 and bovine viral diarrhea virus in cattle from Minas Gerais State, Brazil. Vet Parasitol 2004; 119(2-3): $97-$ 105. PMid:14746970. http://dx.doi.org/10.1016/j.vetpar.2003.12.002.

Melo CB, Leite RC, Souza GN, Leite RC. Frequência de infecção por Neospora caninum em dois diferentes sistemas de produçáo de leite e fatores predisponentes à infecção em bovinos em Minas Gerais. Rev Bras Parasitol Vet 2001; 10(2): 67-74.

Melo DPG, Silva AC, Ortega-Mora LM, Bastos SA, Boaventura CM. Prevalência de anticorpos anti-Neospora caninum em bovinos das microrregiōes de Goiânia e Anápolis, Goiás, Brasil. Rev Bras Parasitol Vet 2006; 15(3): 105-109. PMid:16978474.

Meneses ID, Andrade MR, Uzêda RS, Bittencourt MV, Lindsay DS, Gondim LFP. Frequency of antibodies against Sarcocystis neurona and Neospora caninum in domestic cats in the state of Bahia, Brazil. Rev Bras 
Parasitol Vet 2014; 23(4): 526-529. PMid:25517534. http://dx.doi. org/10.1590/S1984-29612014080.

Mesquita LP, Nogueira CI, Costa RC, Orlando DR, Bruhn FR, Lopes PFR, et al. Antibody kinetics in goats and conceptuses naturally infected with Neospora caninum. Vet Parasitol 2013; 196(3-4): 327-333. PMid:23537945. http://dx.doi.org/10.1016/j.vetpar.2013.03.002.

Mineo TWP, Alenius S, Näslund K, Montassier HJ, Björkman C. Distribution of antibodies against Neospora caninum, BVDV and BHV-1 among cows in Brazilian dairy herds with reproductive disorders. Rev Bras Parasitol Vet 2006; 15(4): 188-192. PMid:17196123.

Mineo TWP, Carrasco AOT, Marciano JA, Werther K, Pinto AA, Machado RZ. Pigeons (Columba livia) are a suitable experimental model for Neospora caninum infection in birds. Vet Parasitol 2009; 159(2): 149 153. PMid:19027237. http://dx.doi.org/10.1016/j.vetpar.2008.10.024.

Mineo TWP, Carrasco AOT, Raso TF, Werther K, Pinto AA, Machado RZ. Survey for natural Neospora caninum infection in wild and captive birds. Vet Parasitol 2011; 182(2-4): 352-355. PMid:21680099. http:// dx.doi.org/10.1016/j.vetpar.2011.05.022.

Mineo TWP, Silva DAO, Costa GHN, von Ancken ACB, Kasper LH, Souza MA, et al. Detection of IgG antibodies to Neospora caninum and Toxoplasma gondii in dogs examined in a veterinary hospital from Brazil. Vet Parasitol 2001; 98(4): 239-245. PMid:11423182. http://dx.doi. org/10.1016/S0304-4017(01)00441-1.

Mineo TWP, Silva DAO, Näslund K, Björkman C, Uggla A, Mineo JR. Toxoplasma gondii and Neospora caninum serological status of different canine populations from Uberlândia, Minas Gerais. Arq Bras Med Vet Zootec 2004; 56(3): 414-417. http://dx.doi.org/10.1590/S010209352004000300022.

Minervino AHH, Cassinelli ABM, Lima JTR, Soares HS, Malheiros AF, Marcili A, et al. Prevalence of anti-Neospora caninum and anti-Toxoplasma gondii antibodies in dogs from two different indigenous communities in the Brazilian Amazon Region. J Parasitol 2012; 98(6): 1276-1278. PMid:22551468. http://dx.doi.org/10.1645/GE-3151.1.

Minervino AHH, Ragozo AMA, Monteiro RM, Ortolani EL, Gennari SM. Prevalence of Neospora caninum antibodies in cattle from Santarém, Pará, Brazil. Res Vet Sci 2008; 84(2): 254-256. PMid:17619028. http:// dx.doi.org/10.1016/j.rvsc.2007.05.003.

Modolo JR, Stachissini AVM, Gennari SM, Dubey JP, Langoni H, Padovani CR, et al. Freqüência de anticorpos anti-Neospora caninum em soros de caprinos do estado de São Paulo e sua relação com o manejo dos animais. Pesq Vet Bras 2008; 28(12): 597-600. http://dx.doi.org/10.1590/ S0100-736X2008001200006.

Moraes CCG, Megid J, Pituco EM, Okuda LH, Del Fava C, Stefano E, et al. Ocorrência de anticorpos anti-Neospora caninum em cães da microrregião da Serra de Botucatu, Estado de São Paulo, Brasil. Rev Bras Parasitol Vet 2008; 17(1): 1-6. PMid:18554432. http://dx.doi. org/10.1590/S1984-29612008000100001.

Moraes LMB, Raimundo JM, Guimarães A, Santos HA, Macedo GL Jr, Massard CL, et al. Occurrence of anti-Neospora caninum and antiToxoplasma gondii IgG antibodies in goats and sheep in western Maranhão, Brazil. Rev Bras Parasitol Vet 2011; 20(4): 312-317. PMid:22166386. http://dx.doi.org/10.1590/S1984-29612011000400010.

Morikawa VM, Zimpel CK, Paploski IAD, Lara MCCSH, Villalobos EMC, Romaldini AHCN, et al. Occurrences of anti-Toxoplasma gondii and antiNeospora caninum antibodies in Barbary sheep at Curitiba zoo, southern Brazil. Rev Bras Parasitol Vet 2014; 23(2): 255-259. PMid:25054509. http://dx.doi.org/10.1590/S1984-29612014034.
Moura AB, Silva MO, Farias JA, Vieira-Neto A, Souza AP, Sartor AA, et al. Neospora spp. antibodies in horses from two geographical regions of the state of Santa Catarina, Brazil. Rev Bras Parasitol Vet 2013; 22(4): 597-601. PMid:24473888. http://dx.doi.org/10.1590/S1984-29612013000400023.

Munhoz AD, Amaral TF, Gonçalves LR, Moraes VMB, Machado RZ. Gallus gallus domesticus are resistant to infection with Neospora caninum tachyzoites of the NC-1 strain. Vet Parasitol 2014; 206(3-4): 123-128. PMid:25468016. http://dx.doi.org/10.1016/j.vetpar.2014.10.009.

Munhoz AD, Flausino W, Silva RT, Almeida CRR, Lopes CWG. Distribuição de anticorpos contra Neospora caninum em vacas leiteiras dos municípios de Resende e Rio Claro, Estado do Rio de Janeiro, Brasil. Rev Bras Parasitol Vet 2006; 15(3): 101-104. PMid:16978473.

Munhoz AD, Mineo TWP, Alessi AC, Lopes CWG, Machado RZ. Assessment of experimental infection for dogs using Gallus gallus chorioallantoic membranes inoculated with Neospora caninum. Rev Bras Parasitol Vet 2013; 22(4): 565-570. PMid:24473883. http://dx.doi. org/10.1590/S1984-29612013000400018.

Munhoz AD, Pereira MJS, Flausino W, Lopes CWG. Neospora caninum seropositivity in cattle breeds in the South Fluminense Paraíba Valley, state of Rio de Janeiro. Pesq Vet Bras 2009; 29(1): 29-32. http://dx.doi. org/10.1590/S0100-736X2009000100004.

Muradian V, Ferreira LR, Lopes EG, Esmerini PO, Pena HFJ, Soares RM, et al. A survey of Neospora caninum and Toxoplasma gondii infection in urban rodents from Brazil. J Parasitol 2012; 98(1): 128-134. PMid:21790367. http://dx.doi.org/10.1645/GE-2817.1.

Nascimento COM, Silva MLCR, Kim PCP, Gomes AAB, Gomes ALV, Maia RCC, et al. Occurrence of Neospora caninum and Toxoplasma gondii DNA in brain tissue from hoary foxes (Pseudalopex vetulus) in Brazil. Acta Trop 2015; 146: 60-65. PMid:25746974. http://dx.doi.org/10.1016/j. actatropica.2015.02.016.

Nascimento EE, Sammi AS, Santos JR, Nino BSL, Bogado ALG, Taroda A, et al. Anti-Neospora caninum antibody detection and vertical transmission rate in pregnant zebu beef cows (Bos indicus): Neospora caninum in pregnant beef cows (Bos indicus). Comp Immunol Microbiol Infect Dis 2014; 37(4): 267-270. PMid:25193073. http://dx.doi.org/10.1016/j. cimid.2014.08.002

Nogueira CI, Mesquita LP, Abreu CC, Nakagaki KYR, Seixas JN, Bezerra PS, et al. Risk factors associated with seroprevalence of Neospora caninum in dogs from urban and rural areas of milk and coffee production in Minas Gerais state, Brazil. Epidemiol Infect 2013; 141(11): 2286-2293. PMid:23419686. http://dx.doi.org/10.1017/S0950268813000162.

Norlander E. Seroprevalence of Toxoplasma gondii and Neospora spp. in equids from three municipalities in Pará, Brazil [Dissertation]. Uppsala: Swedish University of Agricultural Sciences; 2014.

Ogawa L, Freire RL, Vidotto O, Gondim LFP, Navarro IT. Occurrence of antibodies to Neospora caninum and Toxoplasma gondii in dairy cattle from the northern region of the Paraná State, Brazil. Arq Bras Med Vet Zootec 2005; 57(3): 312-316. http://dx.doi.org/10.1590/S010209352005000300006 .

Oliveira JM, Matos MFC, Oshiro LM, Andreotti R. Prevalence of antiNeospora caninum antibodies in dogs in the urban area of Campo Grande, MS, Brazil. Rev Bras Parasitol Vet 2004; 13(4): 155-158.

Oliveira S, Soares RM, Aizawa J, Soares HS, Chiebao DP, Ortega-Mora LM, et al. Isolation and biological and molecular characterization of Neospora caninum (NC-SP1) from a naturally infected adult asymptomatic cattle (Bos taurus) in the state of São Paulo, Brazil. Parasitology 2017; 144(6): 707711. PMid:28073388. http://dx.doi.org/10.1017/S0031182016002481. 
Oliveira UV, Magalhães VCS, Almeida CP, Santos IA, Mota DA, Macêdo LS, et al. Quails are resistant to infection with Neospora caninum tachyzoites. Vet Parasitol 2013; 198(1-2): 209-213. PMid:24041486. http://dx.doi. org/10.1016/j.vetpar.2013.08.009.

Onuma SSM, Melo ALT, Kantek DLZ, Crawshaw-Junior PG, Morato RG, May-Júnior JA, et al. Exposure of free-living jaguars to Toxoplasma gondii, Neospora caninum and Sarcocystis neurona in the Brazilian Pantanal. Rev Bras Parasitol Vet 2014; 23(4): 547-553. PMid:25517539. http:// dx.doi.org/10.1590/S1984-29612014077.

Oshiro LM, Matos MFC, Oliveira JM, Monteiro LARC, Andreotti R. Prevalence of anti-Neospora caninum antibodies in cattle from the state of Mato Grosso do Sul, Brazil. Rev Bras Parasitol Vet 2007; 16(3): 133-138. PMid:18078599. http://dx.doi.org/10.1590/S1984-29612007000300004.

Oshiro LM, Motta-Castro ARC, Freitas SZ, Cunha RC, Dittrich RL, Meirelles ACF, et al. Neospora caninum and Toxoplasma gondii serodiagnosis in human immunodeficiency virus carriers. Rev Soc Bras Med Trop 2015; 48(5): 568-572. PMid:26516966. http://dx.doi.org/10.1590/00378682-0151-2015.

Paiz LM, Silva RC, Menozzi BD, Langoni H. Antibodies to Neospora caninum in sheep from slaughterhouses in the state of São Paulo, Brazil. Rev Bras Parasitol Vet 2015; 24(1): 95-100. PMid:25909261. http:// dx.doi.org/10.1590/S1984-29612015009.

Paulan SC, Lins AGS, Tenório MS, Silva DT, Pena HFJ, Machado RZ, et al. Seroprevalence rates of antibodies against Leishmania infantum and other protozoan and rickettsial paraites in dogs. Rev Bras Parasitol Vet 2013; 22(1): 162-166. PMid:24252965. http://dx.doi.org/10.1590/ S1984-29612013000100031.

Paz GF, Leite RC, Rocha MA. Associação entre sorologia para Neospora caninum e taxa de prenhez em vacas receptoras de embrióes. Arq Bras Med Vet Zootec 2007; 59(5): 1323-1325. http://dx.doi.org/10.1590/ S0102-09352007000500034.

Pena HFJ, Soares RM, Ragozo AMA, Monteiro RM, Yai LEO, Nishi $\mathrm{SM}$, et al. Isolation and molecular detection of Neospora caninum from naturally infected sheep from Brazil. Vet Parasitol 2007; 147(1-2): 6166. PMid:17451882. http://dx.doi.org/10.1016/j.vetpar.2007.03.002.

Pescador CA, Corbellini LG, Oliveira EC, Raymundo DL, Driemeier D. Histopathological and immunohistochemical aspects of Neospora caninum diagnosis in bovine aborted fetuses. Vet Parasitol 2007; 150(1-2): 159163. PMid:17904290. http://dx.doi.org/10.1016/j.vetpar.2007.08.028.

Pessoa GA, Martini AP, Trentin JM, Dalcin VC, Leonardi CEP, Vogel FSF, et al. Impact of spontaneous Neospora caninum infection on pregnancy loss and subsequent pregnancy in grazing lactating dairy cows. Theriogenology 2016; 85(3): 519-527. PMid:26542136. http://dx.doi. org/10.1016/j.theriogenology.2015.09.034.

Pivoto FL, Macêdo AG Jr, Silva MV, Ferreira FB, Silva DAO, Pompermayer E, et al. Serological status of mares in parturition and the levels of antibodies (IgG) against protozoan family Sarcocystidae from their pre colostral foals. Vet Parasitol 2014; 199(1-2): 107-111. PMid:24183649. http://dx.doi.org/10.1016/j.vetpar.2013.10.001.

Plugge NF, Ferreira FM, Richartz RRTB, Siqueira A, Dittrich RL. Occurrence of antibodies against Neospora caninum and/or Toxoplasma gondii in dogs with neurological signs. Rev Bras Parasitol Vet 2011; 20(3): 202-206. PMid:21961748. http://dx.doi.org/10.1590/S198429612011000300004.

Plugge NF, Montiani-Ferreira F, Richartz RRTB, Dal Pizzol J, Machado PC Jr, Patrício LFL, et al. Frequency of antibodies against Neospora caninum in stray and domiciled dogs from urban, periurban and rural areas from Paraná State, Southern Brazil. Rev Bras Parasitol Vet 2008; 17(4): 222-226. PMid:19265582. http://dx.doi.org/10.1590/S198429612008000400010.

Portella LP, Cadore GC, Sangioni LA, Pellegrini LFV, Fighera R, Ramos F, et al. Antibodies against Apixomplexa protozoa and abscence sarcocysts in heart tissues from horses in southern Brazil. Rev Bras Parasitol Vet 2017; 26(1): 100-103. PMid:28327879. http://dx.doi.org/10.1590/ s1984-29612016068.

Ragozo AMA, Paula VSO, Souza SLP, Bergamaschi DP, Gennari SM. Ocorrência de anticorpos anti-Neospora caninum em soros bovinos procedentes de seis estados brasileiros. Rev Bras Parasitol Vet 2003; 12(1): 33-37.

Raimundo JM, Guimarães A, Moraes LMB, Santos LA, Nepomuceno LL, Barbosa SM, et al. Toxoplasma gondii and Neospora caninum in dogs from the state of Tocantins: serology and associated factors. Rev Bras Parasitol Vet 2015; 24(4): 475-481. PMid:26689184. http://dx.doi. org/10.1590/S1984-29612015068.

Ramos IAS, Silva RJ, Maciel TA, Silva JABA, Fidelis OL, Soares PC, et al. Assessment of transplacental transmission of Neospora caninum in dairy cattle in the Agreste region of Pernambuco. Rev Bras Parasitol Vet 2016; 25(4): 516-522. PMid:27737368. http://dx.doi.org/10.1590/s198429612016055.

Regidor-Cerrillo J, Díez-Fuertes F, García-Culebras A, Moore DP, González-Warleta M, Cuevas C, et al. Genetic diversity and geographic population structure of bovine Neospora canium determined by microsatellite genotyping analysis. PLoS One 2013; 8(8): e72678. PMid:23940816. http://dx.doi.org/10.1371/journal.pone.0072678.

Rezende-Gondim MM, Silva AV, Schares G, Gondim LFP. In contrast to Toxoplasma gondii, Neospora caninum tachyzoites did not sustain multiplication in vitro at increased incubation temperatures. Vet Parasitol 2017; 234: 19-24. PMid:28115178. http://dx.doi.org/10.1016/j. vetpar.2016.12.013.

Rodrigues AAR, Gennari SM, Aguiar DM, Sreekumar C, Hill DE, Miska $\mathrm{KB}$, et al. Shedding of Neospora caninum oocysts by dogs fed tissues from naturally infected water buffaloes (Bubalus bubalis) from Brazil. Vet Parasitol 2004; 124(3-4): 139-150. PMid:15381294. http://dx.doi. org/10.1016/j.vetpar.2004.07.007.

Romanelli PR, Freire RL, Vidotto O, Marana ERM, Ogawa L, Paula VSO, et al. Prevalence of Neospora caninum and Toxoplasma gondii in sheep and dogs from Guarapuava farms, Paraná State, Brazil. Res Vet Sci 2007; 82(2): 202-207. PMid:17266999. http://dx.doi.org/10.1016/j. rvsc.2006.04.001.

Rossi GF, Cabral DD, Ribeiro DP, Pajuaba ACAM, Corrêa RR, Moreira RQ, et al. Evaluation of Toxoplasma gondii and Neospora caninum infections in sheep from Uberlândia, Minas Gerais State, Brazil, by different serological methods. Vet Parasitol 2011; 175(3-4): 252-259. PMid:21075529. http:// dx.doi.org/10.1016/j.vetpar.2010.10.017.

Salaberry SRS, Okuda LH, Nassar AFC, Castro JR, Lima-Ribeiro AMC. Prevalence of Neospora caninum antibodies in sheep flocks of Uberlândia county, MG. Rev Bras Parasitol Vet 2010; 19(3): 148-151. PMid:20943017. http://dx.doi.org/10.1590/S1984-29612010000300004.

Santos APME, Navarro IT, Freire RL, Vidotto O, Bracarense APFRL. Neospora caninum in dairy cattle in Paraná State, Brazil: histological and immunohistochemical analysis in fetuses. Semina Cienc Agrar 2005; 26(4): 559-562. http://dx.doi.org/10.5433/1679-0359.2005v26n4p559.

Sartor IF, Garcia A Fo, Vianna LC, Pituco EM, Dal Pai V, Sartor R. Ocorrência de anticorpos anti-Neospora caninum em bovinos leiteiros e 
de corte da região de Presidente Prudente, SP. Arq Inst Biol (Sao Paulo) 2005; 72(4): 413-418.

Sartor IF, Hasegawa MY, Canavessi AMO, Pinckney RD. Ocorrência de anticorpos de Neospora caninum em vacas leiteiras avaliados pelos métodos ELISA e RIFI no município de Avaré, SP. Semina Cienc Agrar 2003; 24(1): 3-10. http://dx.doi.org/10.5433/1679-0359.2003v24n1p3.

Seabra NM, Pereira VF, Kuwassaki MV, Benassi JC, Oliveira TMFS. Toxoplasma gondii, Neospora caninum, Leishmania spp. serology and Leishmania spp. PCR in dogs from Pirassununga, SP. Rev Bras Parasitol Vet 2015; 24(4): 454-458. PMid:26689180. http://dx.doi.org/10.1590/ S1984-29612015046.

Sicupira PML, Magalhães VCS, Galvão GS, Pereira MJS, Gondim LFP, Munhoz AD. Factors associated with infection by Neospora caninum in dogs in Brazil. Vet Parasitol 2012; 185(2-4): 305-308. PMid:22015062. http://dx.doi.org/10.1016/j.vetpar.2011.09.029.

Silva DAO, Lobato J, Mineo TWP, Mineo JR. Evaluation of serological tests for the diagnosis of Neospora caninum infection in dogs: optimization of cut off titers and inhibition studies of cross-reactivity with Toxoplasma gondii. Vet Parasitol 2007; 143(3-4): 234-244. PMid:16973287. http:// dx.doi.org/10.1016/j.vetpar.2006.08.028.

Silva JB, Nicolino RR, Fagundes GM, Bomjardim HA, Reis ASB, Lima DHS, et al. Serological survey of Neospora caninum and Toxoplasma gondii in cattle (Bos indicus) and water buffaloes (Bubalus bubalis) in ten provinces of Brazil. Comp Immunol Microbiol Infect Dis 2017; 52: 30 35. PMid:28673459. http://dx.doi.org/10.1016/j.cimid.2017.05.005.

Silva JB, Santos PN, Castro GNS, Fonseca AH, Barbosa JD. Prevalence survey of selected bovine pathogens in water buffaloes in the north region of Brazil. J Parasitol Res 2014; 2014: 603484. PMid:24563780. http:// dx.doi.org/10.1155/2014/603484.

Silva MIS, Almeida MAO, Mota RA, Pinheiro-Junior JW, Rabelo SSA. Fatores de riscos associados à infecção por Neospora caninum em matrizes bovinas leiteiras em Pernambuco. Cienc Anim Bras 2008; 9(2): 455-461.

Silva MSA, Uzêda RS, Costa KS, Santos SL, Macedo ACC, Abe-Sandes $\mathrm{K}$, et al. Detection of Hammondia heydorni and related coccidia (Neospora caninum and Toxoplasma gondii) in goats slaughtered in Bahia, Brazil. Vet Parasitol 2009; 162(1-2): 156-159. PMid:19278786. http://dx.doi. org/10.1016/j.vetpar.2009.02.007.

Soares HS, Ahid SMM, Bezerra ACDS, Pena HFJ, Dias RA, Gennari SM. Prevalence of anti-Toxoplasma gondii and anti-Neospora caninum antibodies in sheep from Mossoró, Rio Grande do Norte, Brazil. Vet Parasitol 2009a; 160(3-4): 211-214. PMid:19091473. http://dx.doi. org/10.1016/j.vetpar.2008.10.102.

Soares HS, Ramos VN, Osava CF, Oliveira S, Szabó MPJ, Piovezan $\mathrm{U}$, et al. Occurrence of antibodies against Neospora caninum in wild pigs (Sus scrofa) in the Pantanal, Mato Grosso do Sul, Brazil. Braz J Vet Res Anim Sci 2016; 53(1): 112-116. http://dx.doi.org/10.11606/issn.16784456.v53i1p112-116.

Soares RM, Cortez LRPB, Gennari SM, Sercundes MK, Keid LB, Pena HFJ. Crab-eating fox (Cerdocyon thous), a South American canid, as a definitive host for Hammondia heydorni. Vet Parasitol 2009b; 162(1-2): 46-50. PMid:19303215. http://dx.doi.org/10.1016/j.vetpar.2009.02.003.

Sousa KCM, Herrera HM, Domingos IH, Campos JBV, Santos IMC, Neves $\mathrm{HH}$, et al. Serological detection of Toxoplasma gondii, Leishmania infantum and Neospora caninum in cats from an area endemic for leishmaniasis in Brazil. Rev Bras Parasitol Vet 2014; 23(4): 449-455. PMid:25517522. http://dx.doi.org/10.1590/S1984-29612014078.
Sousa ME, Porto WJN, Albuquerque PPF, Souza OL No, Pinheiro JW, Mota RA. Seroprevalence of antibodies to Neospora caninum in dogs in the state of Alagoas, Brazil. Rev Bras Parasitol Vet 2012; 21(3): 287-290. PMid:23070441. http://dx.doi.org/10.1590/S1984-29612012000300019.

Souza LM, Nascimento AA, Furuta PI, Basso LMS, Silveira DM, Costa AJ. Detecção de anticorpos contra Neospora caninum e Toxoplasma gondii em soros de bubalinos (Bubalus bubalis) no Estado de São Paulo, Brasil. Semina Cienc Agrar 2001; 22(1): 39-48. http://dx.doi.org/10.5433/16790359.2001v22n1p39.

Souza SLP, Guimarães JS, Ferreira F, Dubey JP, Gennari SM. Prevalence of Neospora caninum antibodies in dogs from dairy cattle farms in Paraná, Brazil. J Parasitol 2002; 88(2): 408-409. PMid:12054023. http://dx.doi. org/10.1645/0022-3395(2002)088[0408:PONCAI]2.0.CO;2.

Stelmann UJP, Ullmann LS, Langoni H, Amorim RM. Equine neosporosis: search for antibodies in cerebrospinal fluid and sera from animals with history of ataxia. Rev Bras Med Vet 2011; 33(2): 99-102.

Taques IIGG, Barbosa TR, Martini AC, Pitchenin LC, Braga ÍA, Melo ALT, et al. Molecular assessment of the transplacental transmission of Toxoplasma gondii, Neospora caninum, Brucella canis and Ehrlichia canis in dogs. Comp Immunol Microbiol Infect Dis 2016; 49: 47-50. PMid:27865263. http://dx.doi.org/10.1016/j.cimid.2016.09.002.

Teixeira WC, Silva MIS, Pereira JG, Pinheiro AM, Almeida MAO, Gondim LFP. Freqüência de cães reagentes para Neospora caninum em São Luís, Maranhão. Arq Bras Med Vet Zootec 2006; 58(4): 685-687. http://dx.doi.org/10.1590/S0102-09352006000400038.

Teixeira WC, Uzêda RS, Gondim LFP, Silva MIS, Pereira HM, Alves LC, et al. Prevalência de anticorpos anti-Neospora caninum (Apicomplexa: Sarcocystidae) em bovinos leiteiros de propriedades rurais em três microrregióes no estado do Maranhão. Pesq Vet Bras 2010; 30(9): 729 734. http://dx.doi.org/10.1590/S0100-736X2010000900004.

Tembue AASM, Ramos RAN, Sousa TR, Albuquerque AR, Costa AJ, Meunier IMJ, et al. Serological survey of Neospora caninum in small ruminants from Pernambuco State, Brazil. Rev Bras Parasitol Vet 2011; 20(3): 246-248. PMid:21961757. http://dx.doi.org/10.1590/S198429612011000300013.

Tiemann JCH, Rodrigues AAR, Souza SLP, Duarte JMB, Gennari SM. Occurrence of anti-Neospora caninum antibodies in Brazilian cervids kept in captivity. Vet Parasitol 2005a; 129(3-4): 341-343. PMid:15845290. http://dx.doi.org/10.1016/j.vetpar.2004.12.016.

Tiemann JCH, Souza SLP, Rodrigues AAR, Duarte JMB, Gennari SM. Environmental effect on the occurrence of anti-Neospora caninum antibodies in pampas-deer (Ozotoceros bezoarticus). Vet Parasitol 2005b; 134(1-2): 73-76. PMid:16112811. http://dx.doi.org/10.1016/j.vetpar.2005.07.015.

Topazio JP, Weber A, Camillo G, Vogel FF, Machado G, Ribeiro A, et al. Seroprevalence and risk factors for Neospora caninum in goats in Santa Catarina state, Brazil. Rev Bras Parasitol Vet 2014; 23(3): 360-366. PMid:25271457. http://dx.doi.org/10.1590/S1984-29612014062.

Toscan G, Vogel FSF, Cadore GC, Cezar AS, Sangioni LA, Pereira RCF, et al. Occurrence of antibodies anti-Neospora spp. in cart horses and Crioula breed horses from Rio Grande do Sul State. Arq Bras Med Vet Zootec 2011; 63(1): 258-261. http://dx.doi.org/10.1590/S010209352011000100038 .

Truppel JH, Montiani-Ferreira F, Lange RR, Vilani RGOC, Reifur L, Boerger W, et al. Detection of Neospora caninum DNA in capybaras and 
phylogenetic analysis. Parasitol Int 2010; 59(3): 376-379. PMid:20470895. http://dx.doi.org/10.1016/j.parint.2010.05.001.

Ueno TEH, Gonçalves VSP, Heinemann MB, Dilli TLB, Akimoto BM, Souza SLP, et al. Prevalence of Toxoplasma gondii and Neospora caninum infections in sheep from Federal District, central region of Brazil. Trop Anim Health Prod 2009; 41(4): 547-552. PMid:18726165. http://dx.doi. org/10.1007/s11250-008-9220-8.

Uzêda RS, Costa KS, Santos SL, Pinheiro AM, Almeida MAO, McAllister MM, et al. Loss of infectivity of Neospora caninum oocyts maintained for a prolonged time. Korean J Parasitol 2007a; 45(4): 295-299. PMid:18165712. http://dx.doi.org/10.3347/kjp.2007.45.4.295.

Uzêda RS, Pinheiro AM, Fernández SY, Ayres MCC, Gondim LFP, Almeida MAO. Seroprevalence of Neospora caninum in dairy goats from Bahia, Brazil. Small Rumin Res 2007b; 70(2-3): 257-259. http://dx.doi. org/10.1016/j.smallrumres.2006.04.003.

Valadas S, Gennari SM, Yai LEO, Rosypal AC, Lindsay DS. Prevalence of antibodies to Trypanosoma cruzi, Leishmania infantum, Encephalitozoon cuniculi, Sarcocystis neurona, and Neospora caninum in capybara, Hydrochoerus hydrochaeris, from São Paulo State, Brazil. J Parasitol 2010a; 96(3): 521524. PMid:20020808. http://dx.doi.org/10.1645/GE-2368.1.

Valadas S, Minervino AHH, Lima VMF, Soares RM, Ortolani EL, Gennari SM. Occurrence of antibodies anti-Neospora caninum, anti-Toxoplasma gondii, and anti-Leishmania chagasi in serum of dogs from Pará State, Amazon, Brazil. Parasitol Res 2010b; 107(2): 453-457. PMid:20445991. http://dx.doi.org/10.1007/s00436-010-1890-2.

Varandas NP, Rached PA, Costa GHN, Souza LM, Castagnolli KC, Costa AJ. Freqüência de anticorpos anti-Neospora caninum e anti-Toxolasma gondii em cães da regiâo nordeste do Estado de São Paulo. Correlação com neuropatias. Semina Cienc Agrar 2001; 22(1): 105-111. http:// dx.doi.org/10.5433/1679-0359.2001v22n1p105.

Varaschin MS, Hirsch C, Wouters F, Nakagaki KY, Guimarães AM, Santos DS, et al. Congenital neosporosis in goats from the State of Minas Gerais, Brazil. Korean J Parasitol 2012; 50(1): 63-67. PMid:22451736. http://dx.doi.org/10.3347/kjp.2012.50.1.63.
Viana RB, Del Fava C, Moura ACB, Cardoso EC, Araújo CV, Monteiro BM, et al. Ocorrência de anticorpos anti-Neospora caninum, Brucella sp. e Leptospira spp. em búfalos (Bubalus bubalis) criados na Amazônia. Arq Inst Biol (Sao Paulo) 2009; 76(3): 453-457.

Villalobos EMC, Furman KE, Lara MCCSH, Cunha EMS, Finger MA, Busch APB, et al. Detection of Neospora sp. antibodies in cart horses from urban areas of Curitiba, Southern Brazil. Rev Bras Parasitol Vet 2012; 21(1): 68-70. PMid:22534949. http://dx.doi.org/10.1590/ S1984-29612012000100014.

Villalobos EMC, Ueno TEH, Souza SLP, Cunha EMS, Lara MCCSH, Gennari SM, et al. Association between the presence of serum antibodies against Neospora spp. and fetal loss in equines. Vet Parasitol 2006; 142(3-4): 372-375. PMid:16962708. http://dx.doi.org/10.1016/j.vetpar.2006.07.016.

Vitaliano SN, Silva DAO, Mineo TWP, Ferreira RA, Bevilacqua E, Mineo JR. Seroprevalence of Toxoplasma gondii and Neospora caninum in captive maned wolves (Chrysocyon brachyurus) from southeastern and midwestern regions of Brazil. Vet Parasitol 2004; 122(4): 253-260. PMid:15262003. http://dx.doi.org/10.1016/j.vetpar.2004.04.004.

Vogel FSF, Arenhart S, Bauermann FV. Anticorpos anti-Neospora caninum em bovinos, ovinos e bubalinos no Estado do Rio Grande do Sul. Cienc Rural 2006; 36(6): 1948-1951. http://dx.doi.org/10.1590/ S0103-84782006000600048.

Yai LEO, Cañon-Franco WA, Geraldi VC, Summa MEL, Camargo MCGO, Dubey JP, et al. Seroprevalence of Neospora caninum and Toxoplasma gondii antibodies in the South American opossum (Didelphis marsupialis) from the city of São Paulo, Brazil. J Parasitol 2003; 89(4): 870-871. PMid:14533710. http://dx.doi.org/10.1645/GE-83R.

Yai LEO, Ragozo AMA, Cañón-Franco WA, Dubey JP, Gennari SM. Occurrence of Neospora caninum antibodies in capybaras (Hydrochaeris hydrochaeris) from São Paulo State, Brazil. J Parasitol 2008; 94(3): 766. PMid:18605804. http://dx.doi.org/10.1645/GE-1468.1.

Zimpel CK, Grazziotin AL, Barros IR Fo, Guimarães AMS, Santos LC, Moraes W, et al. Occurrence of antibodies anti-Toxoplasma gondii, Neospora caninum and Leptospira interrogans in a captive deer herd in Southern Brazil. Rev Bras Parasitol Vet 2015; 24(4): 482-487. PMid:26689185. http://dx.doi.org/10.1590/S1984-29612015065. 